\title{
Parallel States of Change
}

On Creating Ash

\author{
By \\ Ken Robinson \\ HBA History, Wilfrid Laurier University, 2008
}

A Major Research Paper presented to Ryerson University

in partial fulfillment of the

requirements for the degree of

Master of Fine Arts

in the Program of

Documentary Media

Toronto, Ontario, Canada, 2017

(C) Kenneth Robinson 2017 


\section{Authors Declaration}

I hereby declare that I am the sole author of this thesis. This is a true copy of the thesis as accepted by my examiners. I authorize Ryerson University to lend this thesis to other institutions or individuals for the purpose of scholarly research. I further authorize Ryerson University to reproduce this thesis by photocopying or by other means, in total or in part, at the request of other institutions or individuals for the purpose of scholarly research. I understand that my thesis may be made electronically available to the public.

\section{Acknowledgments}

I wish to acknowledge and thank the Ontario Graduate Scholarship for funding this project. The main thanks need to go out to my parents, acknowledged as the Lady and Jim in the credits. I'm glad I can keep doing things that make you happy. Thank you to Gerda and Pierre for your consistent help and guidance through this process and to Don Snyder for helping kick start it all. To my friends in Korea, thank you for participating in this process, it would not have happened without you. And a big thank you to Summer. You got me here. 


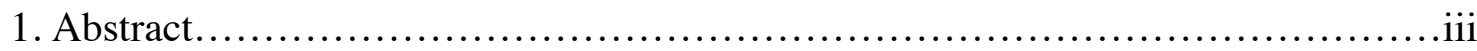

2. Project Description................................................... 1

3. Historical and Social Context............................................... 3

4. Social Themes......................................................... 12

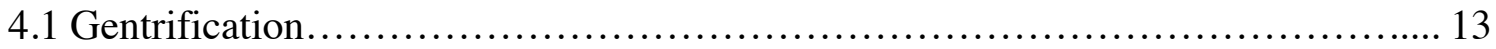

4.2 Social Rebellion.......................................................... 15

4.3 Art................................................................. 19

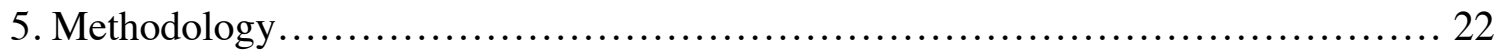

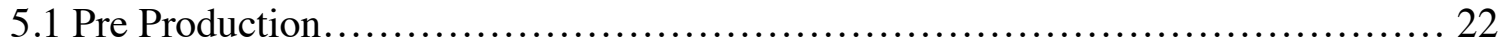

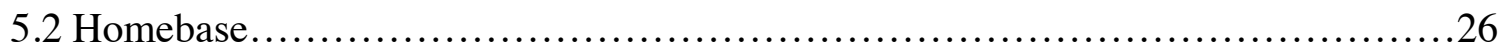

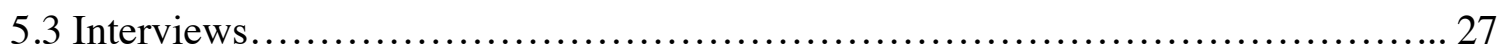

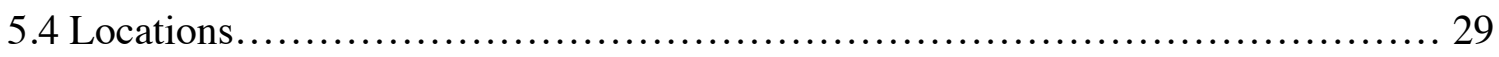

5.5 Post and Pace ................................................................. 31

6. Documentary Relevance................................................ 32

6.1 Where Ash is unavoidably a music documentary............................ 33

6.2 Where Ash tries really hard to not be a standard music doc...................... 34

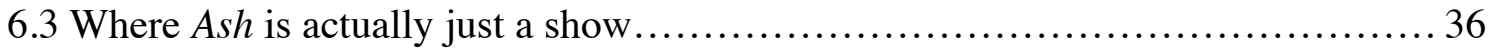

6.4 Punk Documentary................................................... 37

6.5 Subculture Representation............................................... 42

6.6 The Stuff That B-Roll is Made Out Of.................................... 43

7. Drifting Smoke............................................................. 44 


\section{Abstract}

This thesis paper was written in support of the short documentary film Ash, a sociocultural exploration of two Seoul punk venues and the scenes that formed around them. Ash is a film that co-opts the music documentary form in order to re-examine ideas surrounding cultural and gender norms. It follows no strict genre rules and often relies on punk style and humour to maintain a greater sense of verisimilitude.

In Ash we learn about people struggling to assert their identities against the oppressive narrative of a dominant culture, about how they eschew simple satisfactions in the struggle to pursue individual happiness. Defying stereotypes of race, gender, or cultural expectations, it is a film of hope and purpose. It is a story about living a life within a closed system. Above all else, Ash is a story of struggle, triumph, and defeat.

An elegy to the loser's victory. 


\section{Project Description}

In years past, Seoul's punks spent much of their performance and leisure time in the Hongik University District of Western Seoul, Hongdae. In recent years rapid gentrification has forced artists and musicians out of Hongdae and into the surrounding areas. Shot during the summer of 2016, the film Ash explores two scenes/venues (Club Sharp and GBN LiveHouse) that emerged in the aftermath of these changes.

The film is edited under the scope of what Carl Plantinga calls relative objectivity. ${ }^{l}$ Although all events, characters, and words are real, characters become avatars of ideas rather than representations of their actual selves. The film is not cinema verité nor is it direct cinema. It does not propose to give a fully accurate and comprehensive slice of life in Korea. Instead, it endeavours to explore social issues through the real life thoughts and actions of the characters in the film.

In explaining the methodology for studying punk, Stacy Thompson states that, “...each punk scene amasses myriad artefacts within the social field that it establishes..."2 I tried my best when making Ash to follow this line of thinking. Rather than focusing purely on external comparisons and referents, Ash relies on the opinions and lives of the scene's internal agents.

Ash's characters are, in general, artists and performers. As such they possess a public and a private persona. The separation of these personalities is often invisible to all but their closest friends. At best, these personalities synthesise into an outward facing front. Through the pairing and fusion of this obvious public persona and the hidden

\footnotetext{
${ }^{1}$ Carl R. Plantinga, Rhetoric and Representation in Nonfiction Film, (Cambridge, U.K.:

2 Stacy, Thompson, Punk Productions: Unfinished Business, (Albany: State University of New York Press) 2004, 9
} 
private, Ash looks to unravel a viewer's preconceptions about a character's public persona. Ideally this leads to a more nuanced reading of Ash and its subjects. ${ }^{3}$

Ash itself is a film about finding alternative ways to define one's life. Too often we rely on conspicuous consumption or career based status to evaluate how successful somebody is. In Ash almost no character could be declared successful by the terms society sets. Yet every character in the film is satisfied in their own way. They find meaning in life through their art and community. They live in a way that should be inspiring to all. They are defined by doing rather than being.

As for the construction of this paper, I will first introduce a brief history of contemporary Korea for socio-political context. Following this is an analysis and contextualization of the social themes covered in Ash, then a look at the methodology in creating the film, and last a look at where Ash fits into the documentary landscape. Of course, it is more than helpful to have viewed Ash in its entirety before approaching this support paper.

\section{Historical Context}

Ash is a film that takes place exclusively in Korea. In order to have a deeper understanding of the social and cultural themes of the film, it is important to possess, at the very least, a vague understanding of contemporary Korean history. This would mean knowledge of $20^{\text {th }}$ century Korea, from Japanese occupation to present day political unrest and upheaval. In becoming acquainted with this abbreviated history it will be

\footnotetext{
${ }^{3}$ Leigh H Edwards, "Chasing the Real: Reality Television and Documentary Forms" in Rhodes, Gary Don, and John Parris Springer, Docufictions: Essays on the Intersection of Documentary and Fictional Filmmaking (Jefferson, NC: McFarland \& Co., 2006) 256, 257, 262
} 
much easier to understand the creative and narrative nuance within Ash as well as providing curious viewers the ability to grasp some of the deeper subtext in the film. As punk movements are typically borne from the compulsion to resist the rigidity of class and cultural hierarchies, this context is everything. ${ }^{4}$

Korea's welcome to the $20^{\text {th }}$ century was inhospitable at best and has since been dubbed the, "Dark Period". ${ }^{5}$ On the heels of the Sino-Russian war, Japan sought to increase both its influence and security within the North-East Pacific region. In 1905, using the threat of Russian invasion as justification and with the support of global powers as permission, the Empire of Japan made Korea, then the kingdom of Joseon, a protectorate and formally annexed the Joseon Kingdom in $1910 .^{6}$

During the next forty years of occupation, the contiguous history and culture of Korea, one that stretched back to $676 \mathrm{CE}$, faced the threat of erasure. Through the process of forced assimilation, names, cultural practices, art, and language were stripped away by the occupying Japanese. ${ }^{7}$ This period of history has left scars in Korean society that remain to this day. Furthermore, the seeds of modern political and cultural identity began to form during this period. For example, the 1919 March First movement sparked the genesis of Korean demonstration and democracy It was also anti-Japanese sentiment that

\footnotetext{
${ }^{4}$ Brian Fauteux, "“New Noise" Versus the Old Sound: Manifestos and the Shape of Punk to Come," Popular Music and Society, 35, (2012), 479

${ }^{5}$ Michael J. Seth A History of Korea: From Antiquity to the Present (Rowman \& Littlefield, 2011), 266

${ }^{6}$ Alexis Dudden, Japan's Colonization of Korea: Discourse and Power (University of Hawai'i Press, 2005), 7, 9, 15, 17, 48

${ }^{7}$ Dudden, 48, Seth, 25, 296, 297
} 
led to massive protests in the early years of one of Korea's most divisive founding father's, Park Chung Hee's, first attempts at Korean governance. ${ }^{8}$

The geographic boundaries of modern day North and South Korea did not exist until seven years after the Second World War. After gaining their freedom from the Japanese, Korea entered a brief pre-conflict period. Tensions between Captitalist and Communist global movements saw Soviet and American interests competing for control over the peninsula. Political movement in the area was more or less stalled until the 1948 Communist victory in China. With the fate of the middle kingdom decided, tensions on the Korean peninsula reached a flashpoint. The resulting, albeit brief, Korean War (19501952) that followed was responsible for the North/South division that exists today. ${ }^{9}$

Following the signing of the 1952 Armistice that ended open conflict on the peninsula, the first democratically elected government was formed under Rhee Syngman, American sympathizer and member of the Christian faith. His rule was problematic and short lived. He was replaced by his prime minister in 1960 who helped to formed the short-lived Second Republic. The military, including former Japanese commander in Manchuria and high-ranking Korean general Park Chung Hee grew tired of Rhee and his successor's mishandling of the nation's affairs and the country was taken by force..$^{10}$ The Second Republic was officially dissolved in 1961. After taking control of the country,

\footnotetext{
${ }^{8}$ Kyung Moon Hwang, A History of Korea: An Episodic Narrative, 2nd ed, (Palgrave, Macmillan Education, 2017), 138-140, 193, 194

${ }^{9}$ Seth, 308-312, 320-324

${ }_{10}$ Adrian Buzo, The Making of Modern Korea. 3RD ed, (New York: Routledge, 2017), 140, 143, 144
} 
Park Chung Hee and his supporters technically reopened democracy by 1963 where Park was subsequently elected president for two successive terms, the Third Republic. ${ }^{11}$

Continued co-operation with the Americans during this period kept Korea on a path towards poverty and decline. In 1972 Park Chung Hee began the Yusin by political force. Through means of clever policy Park was now a ruler without term limits, now free to pursue policy with no real fear of an expiration date. Unlike the third republic, the fourth republic represented an unmatched economic and social miracle that is still remembered fondly by older generations of Korean citizens. ${ }^{12}$ Through the harmonisation of nationalism and Confucianism, Park Cheong Hee and his compatriots set the stage for modern development and economic success. ${ }^{13}$ During the Third and Fourth republics many of the key elements of Korea's present day economy began to form. ${ }^{14}$ However, it was also during this period where rampant corruption began to pollute society. Lax regulation of government partisans also resulted in the steady creation of what was to be known as Chaebol, massive companies such as Samsung and LG. These vast corporations, which still exist today, worked almost like societies within a society and their internal cultures amplified aspects of traditional hierarchy increasingly which were increasingly found within the fourth republic. ${ }^{15}$

\footnotetext{
${ }^{11}$ Bruce Cumings, Korea's Place in the Sun: A Modern History. (New York: W. W. Norton, 2005), 352, Seth, 406, 407, 411, 418, Buzo, 147

${ }^{12}$ Chung Hee Pak, Our Nation's Path, (West Gate Seoul: Dong-a Publishing, 1962), 28, 29 83, Hwang, 204-206

${ }^{13}$ Andrew Eungi Kim and Gil-sung Park, "Nationalism, Confucianism, Work Ethic and Industrialization in South Korea," Journal of Contemporary Asia 33, no. 1 (2003), 38, 39, Hwang 198-201

${ }^{14}$ Dae-oup Chang, Capitalist Development in Korea: Labour, Capital and the Myth of the Developmental State, (London: Routledge, 2009), 162

${ }^{15} \mathrm{O}$. Yul Kwon, The Korean Economy in Transition: An Institutional Perspective, (Cheltenham, Glos, UK: Edward Elgar, 2010), 58, 59, Hwang, 199, 200
} 
Park was unable to see the dreams of the Yusin Republic fulfilled as he was assassinated in 1980. The fifth republic that replaced him, a similar junta controlled by two consecutive military general presidents, helped to perpetuate the patriarchal exaltation of military elite and military culture. ${ }^{16}$

The return to democracy happened only in 1987 with the first truly free election since the deposition of Rhee Synghman in 1960. Like a nation with Stockholm syndrome, Roh Tae Woo, the candidate put forth by the ruling party, found a path to victory. With a now pluralised and truly open government, the 1987 election formally ended nearly thirty years of authoritarian rule. ${ }^{17}$ Despite the shift in governance the rulers of the sixth republic were reluctant to act against many of the cultural paradigms created by the politics of Park Chung Hee and his successors. This included reconsidering mandatory military conscription of all able-bodied males and moving to reduce or remove the power of the Chaebol. ${ }^{18}$

Development of the sixth republic continued gradually and in tepid fashion until the end of the 1990's. The final shift towards present day Korean society occurred in the aftermath of the 1997 IMF crisis. The policies adopted in this crucible of economic demise led to the neo-liberal reconstruction of Korea's economy today. From this came greater inequality ${ }^{19}$ and the collapse of the old economy. This resulted in numerous

\footnotetext{
${ }^{16}$ Hee Jung Choi and Nora Hui-Jung Kim. 2017, "Of Soldiers and Citizens: Shallow Marketisation, Military Service and Citizenship in Neo-Liberal South Korea," Journal of Contemporary Asia 47 (4): 519

${ }^{17}$ Seth, 418, Buzo, 193, 194

${ }^{18}$ Choi et al., 515, 516, 519, Cumings, 326-328, 398

${ }^{19}$ Iain Pirie, The Korean Developmental State: From Dirigisme to Neo-Liberalism, (New York: Routledge, 2008), 176-177
} 
societal shifts that can be seen prominently in gendered employment statistics, with the number of women employed nationally still not recovering to pre 1997 levels. ${ }^{20}$

Following the neo-liberal restructuring of 1997 the gap between rich and poor has steadily increased, leaving more and more people vulnerable and disenfranchised. ${ }^{21}$ To further exacerbate class divisions, the wealthy were increasingly more capable of receiving lighter service or completely avoiding compulsory military service altogether. ${ }^{22}$ With disenfranchisement comes deviance, in the case of Korea, how much national pride one has is statistically related to how much one perceives inequality. ${ }^{23}$

Park Chung Hee, the father of future president Park Geun Hye, defined his time in governance by an ardent fear of communism and the questioning of restrictive traditions. ${ }^{24}$ Yet within his gaze to the future was a respect for the collectivism and order in Korea's Confucian heritage. In Ash, one can observe how this cultural flotsam has meshed with neo-liberalism in order to create many of the social issues faced by the characters in $A s h .^{25}$ No greater measure of these social pressures can be found than in the passion through which citizens of Korea exercise their democratic rights.

It is worth highlighting that the citizens of Korea were never one to face injustice quietly. The political culture of Korea in the $20^{\text {th }}$ century is one of persistent civil

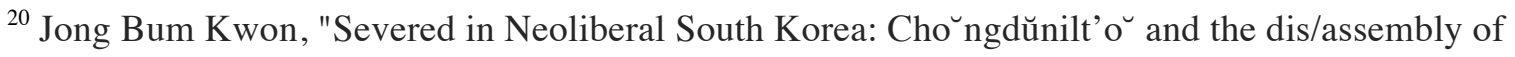
Industrial Bodies," Critique of Anthropology 35, no. 4 (2015), 413

${ }^{21}$ Juyoung Park and Jai S. Mah. 2011, "Neo-Liberal Reform and Bipolarisation of Income in Korea," Journal of Contemporary Asia 41 (2): 250,265, Nancy Abelmann, So Jin Park, and Hyunhee Kim. 2009. "College Rank and neo-liberal Subjectivity in South Korea: The Burden of self-development." Inter-Asia Cultural Studies 10 (2): 229-247, 230-232, Kwon Jong Bum, 413

${ }^{22}$ Choi Hee Jung, 520, 521

${ }^{23}$ Eun Ju Chi, Hyeok Yong Kwon, and Yang Ho Rhee, "Perceived Inequality and the Formation of National Pride in Korea," Korea Observer 45, no. 2 (2014), 169, 176

${ }^{24} \mathrm{Pak}, 63$

${ }^{25}$ Chi et al., 162, 163, Kwan-chun Lee and Sang Kil Han, "Value Harmony as a Social Capital and EHW Factors in Korea," Korea Observer 38, no. 2 (2007), 225, 234, 236, Seth, 154-155
} 
resistance. From the Japanese occupation onwards citizens of both occupied and predemocratic Korea maintained a culture of public demonstration and protest. ${ }^{26}$ Following the IMF crisis Korea went through a period of relative (to its own history) civil calm. Free from the visible bonds of autocrats and puppet governments, the generation that were only children during the IMF crisis entered their trial of protest in 2008. An incoming free trade agreement with the United States looked as if it was going to destabilise the Korean economy much the same as the IMF crisis had. The passions of the masses quickly focused on a singular issue. Beef. Propagandised accounts of Mad Cow disease in the US agricultural system led to massive protests which came close to toppling then president Lee Myeong Bak's government. These subsequent demonstrations helped to re-invigorate the protest culture of another generation. ${ }^{27}$

It only took another seven years before another crisis inspired everyday Koreans to stand up an exert their democratic right to protest. In 2014 a single event would lead to a cascade of protests that united much of the nation in anger and indignation. However, this was an internal crisis, tradition and government fell into the cross hairs of the masses. In the autumn of 2016, the streets of Seoul erupted in mass demonstrations. The decades of corruption and lies that supported the Chaebol and president Park Geun Hye's SaeNuri party were quickly revealed in all their insipient breadth. Change was demanded

\footnotetext{
${ }^{26}$ Seung-Ook Lee, Sook-Jin Kim, and Joel Wainwright. "Mad Cow Militancy: Neoliberal Hegemony and Social Resistance in South Korea," Political Geography 29, no. 7 (2010), 364, Jonson N. Porteux and Sunil Kim. "Public ordering of private coercion: urban redevelopment and democratization in South Korea." Journal of East Asian Studies 16, no. 3 (2016), 376

${ }^{27}$ Lee Seung Ook et al., 363, Buzo, 248, 249
} 
and change was delivered, the government was replaced through democratic election on May $9^{\text {th }} 2017 .^{28}$

So what happened to cause such a big shift? When filming in the summer of 2016 the largest protests in Gwanghwamun Square were a small anti-THAAD demonstration, a persistent Christian anti-homosexuality village, and the longstanding Sewol-Ho encampment in front of the statue of Lee Sun Shin. The shot from the rear of the Sewol monument is a quiet metaphor for the rage that permeates Ash.

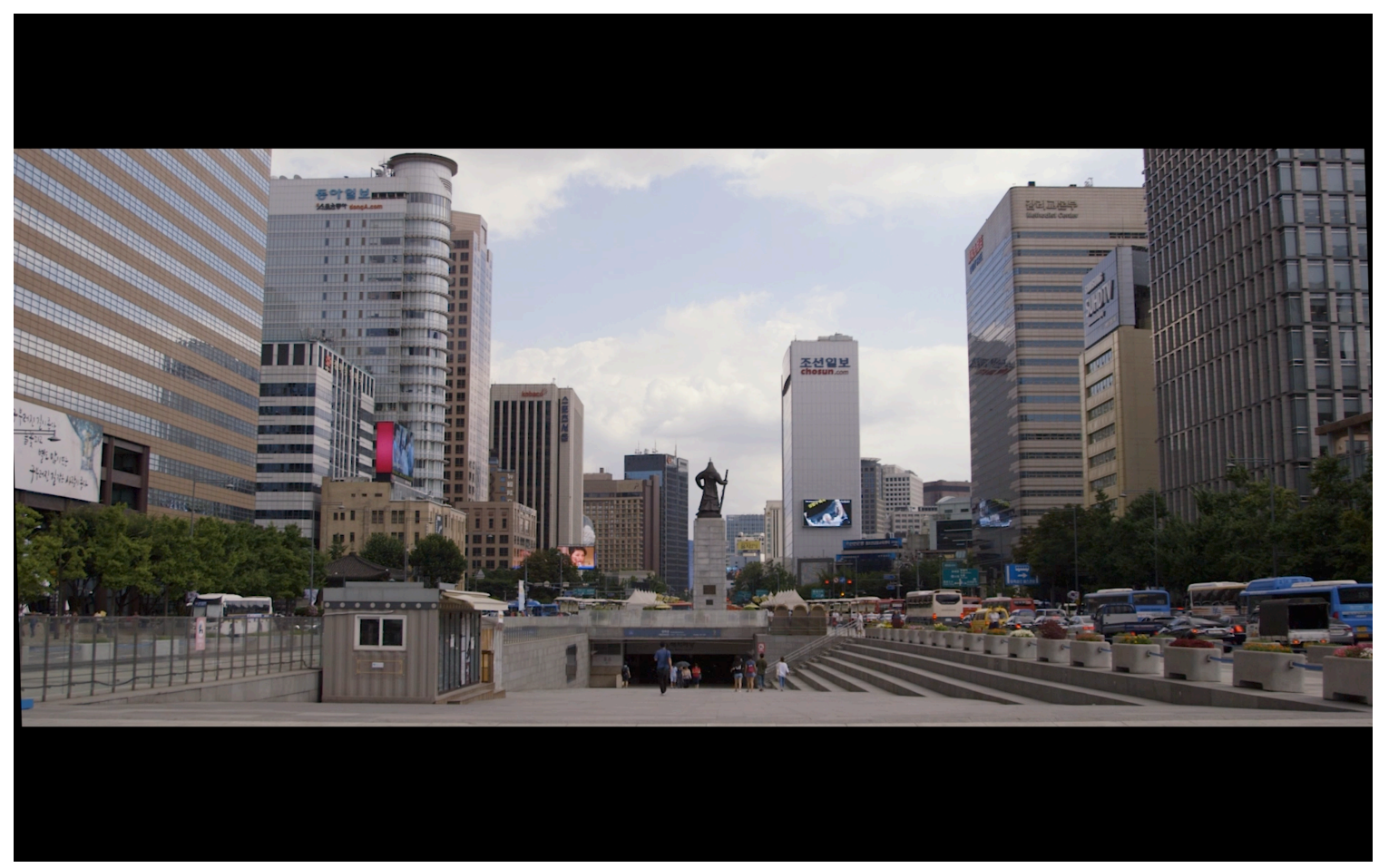

An empty Gwanghwamun from the rear, The Tops of the Sewol encampment are visible at the foot of the statue.

\footnotetext{
${ }^{28}$ Chris Carothers, "The Turning Point for South Korean Democracy," The Diplomat. June 27, 2017, http://thediplomat.com/2017/06/the-turning-point-for-south-korean-democracy/, Yap, Fiona. "How Do South Koreans Respond to Government Corruption," Korean Observer Vol. 47. Iss. 2. 2016, 364, Hwang, 213,214, J. Weston Phippen, "Moon Jae In Wins South Korea's Presidential Election." The Atlantic, May 09, 2017. https://www.theatlantic.com/news/archive/2017/05/south-korea-presidential-election/525942/.
} 
In 2014 the Sewol ferry was bound for the southern Jeju Island. Below deck it carried the graduating class of an Ansan city high-school in addition to cargo that weighed well in excess of regulated limits. Shortly after 08:00 the ship began to yaw and pitch in the heavy waves. ${ }^{29}$ The ballast of the ship had become fatally unbalanced through the decisions of the corrupt company and captain. Shortly after the ocean began to push the vessel around the ferry began to take on water. ${ }^{30}$ Instructions from the captain rang through the loud speakers, "stay inside the ship", as students and teachers dutifully obeyed their captain. The captain however was filled with nothing but cowardice. While those below deck were told to remain, captain and crew were making plans to escape the ship. ${ }^{31}$

As news cameras captured captain Lee Joon-seok and his crew's escape, videos posted to social media showed class seniors comforting or berating their panicked juniors. ${ }^{32}$ With no chance of rescue, the ship sank taking the lives of 300 young people and staff. The hierarchy that existed to maintain order and safety was nothing more than a sham. Those told to listen were selfishly told to die. Society had failed its children.

Such was the anger about that contemporary Korean history now has a pre and post Sewol Korea ${ }^{33}$ With the ousting of Park's corrupt Sae Neuri party so closely following my film, the image of the Sewol-Ho encampment near Ash's first act serves as a metaphor for the rest of the film Ash is the capture of the metaphorical calm before the

\footnotetext{
29여객선 세월호 전복사고 특별조사 보고서 (Sewol Safety Investigation Report), 해양안전심판원 특별조사부 December 29. 2014.

${ }^{30}$ Suk Kyoon Kim, "The SewolFerry Disaster in Korea and Maritime Safety Management." Ocean Development \& International Law 46, no. 4 (2015): 345-358. 346, 355, 356, DPM 220

${ }^{31}$ Kim Suk Kyoon, 348

${ }^{32}$ At the time of writing this support paper footage could be found at the following url's, https://www.youtube.com/watch?v=7sLf9nT0a20, https://www.youtube.com/watch?v=dVEfPP8zLLc

${ }^{33}$ Yap, 364, Hwang, 245
} 
storm. It is a partial collection of the social ills and grievances that helped lead to great social change. Ash captures the frustration of the youth and youthful against a cultural norm that demands adherence only under convenience. In its ugliness and its beauty, the subculture documented in Ash is an immune response to society's ills.

In many ways $A s h$ is a message to those who question undeserved obedience. It is a film that shows life between history's margins. In an interview I was asked whether or not I felt that I had missed an opportunity to film the protests that led to Park's downfall. My honest answer was, "No." If anything, Ash's distance from it increases the film's significance. It is an accurate capture of the anger and indignation of a society at odds with itself. Ash is a film that captures the conditions inside of a bomb before it explodes. It is a unique portrait of rage before change in the post Park era.

\section{Social Themes}

The short documentary form is a poor fit for comprehensive analyses or surveys. Editing one is an exercise in accepting narrative concessions as you watch characters drift into the abyss. It was difficult to make Ash the way I wanted to, but I think I got close. The film is designed to inspire others while interrupting standard narratives about normative behaviours and expectations.

Although intrinsically about the global culture of punk, Ash is wholly about life in Korea. Because of this I had to accept that Ash would sometimes speak about ideas that were obvious to cultural insiders while simultaneously missing narrative points crucial for an outsider's understanding. This meant that certain social aspects of Korean culture such as education and family life had to be left out of the documentary. Furthermore, in 
the recently crowded Korean punk documentary landscape, in order to prevent Ash from being redundant I needed the film to be relevant. This meant focusing away from themes that other creators had covered and instead filling in perceived blanks that others may have left. If anyone wishes to further explore the subject of my documentary, I recommended the following films about the Korean scenes 노후대책없다(No Money No Future) (2016) and Under The Influence: New York Hardcore (2015), Party 51+ (2014), Us \& Them: Korean Indie Rock in a K-Pop World (2015), and Bamseom Pirates Seoul Inferno (2017).

That being said, Ash covers three main themes; gentrification, social rebellion, and art. Woven through these main themes is a dialogue about sexism, racism, feminism, and self-determinism. Neo-liberal growth has lead to an increasingly prominent wage gap and progressively less secure employment. ${ }^{34}$ On occasion the term Hell Joseon has been used by today's youth to describe their lives. The feeling is that if you are born without a silver spoon, you are condemned to a life of struggle and torment. ${ }^{35}$ The characters in Ash are those to whom society no longer speaks.

\subsection{Gentrification}

From 2006 until now the Hongdae district has undergone a gradual, by Korean standards, process of gentrification. As of writing this, the process is nearly complete. ${ }^{36}$ The final blow was likely delivered by the construction of the Gyeongui Line Forest

\footnotetext{
${ }^{34}$ Pririe, $183-185$

${ }^{35}$ Gyong-Mok No and Sang-Yong Park. "나라 탓하는 '헬 조선'...부모 탓하는 '흙수저'" Hankyung.com, 2015, http://www.hankyung.com/news/app/newsview.php?aid=2015100480831

${ }^{36} \mathrm{Ji}$ Youn Kim, "Cultural Entrepreneurs and Urban Regeneration in Itaewon, Seoul." Cities 56, (2016): 132-140, 136
} 
Park, an urban green belt stretching from north-central Seoul, cutting across the North edge of Hongdae, and through the nearby (and previously artist populated) Yeonnam Dong. The park has caused rent in a $600 \mathrm{M}$ radius from the park to skyrocket and resulted in businesses vacating. ${ }^{37}$ The post-script for Hongdae is easily summarised by Park Se Hoon, "The Hongdae area, once a place for avant-garde artists, has been transformed into an iconic commercial zone filled with clubs, restaurants, and fashion shops." ${ }^{38}$ Silent pressure from the neo-liberal reality, gentrification, and migration is the first theme introduced in $A s h .^{39}$

I traveled back to Korea in the summer of 2017 with the intention of getting pickup shots. It did not work out. Most of the buildings and areas that I shot in 2016 were gone. Hongdae had completely changed from the previous summer. In place of the pyramid of prayers was a two-story pedestrian complex. It completely hid the meat restaurants behind it, a grim reminder of the grease pans attached to it.

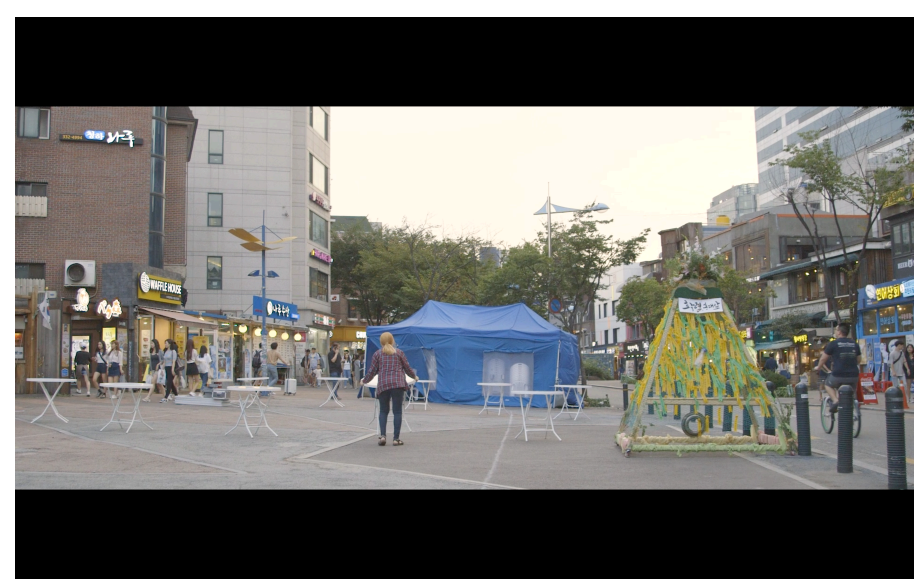

Pyramid of prayers with fire pan (bottom centre)

\footnotetext{
${ }^{37}$ Yoonku Kwon, Shinha Joo, Soyoung Han, and Chan Park. "Mapping the Distribution Pattern of Gentrification Near Urban Parks in the Case of Gyeongui Line Forest Park, Seoul, Korea." Sustainability 9, no. 2 (2017), 14

${ }^{38}$ Se Hoon Park. "Can we Implant an Artist Community? A Reflection on Government-Led Cultural Districts in Korea." Cities 56, (2016), 175

${ }^{39}$ Kai Potter, "Is Hongdae going south? Only to Hapjeong, Sangsu and Mangwon." The Korea Herald. August 09, 2017, http://www.koreaherald.com/view.php?ud=20170809000801
} 
The most shocking of the changes was the transformation of the park in which we first meet Lee Juyoung. This landmark of Korean punk history had completely changed. The playground equipment was gone and the large bathroom building was painted over, sanitised. ${ }^{40}$ It was as if subculture had never existed there.

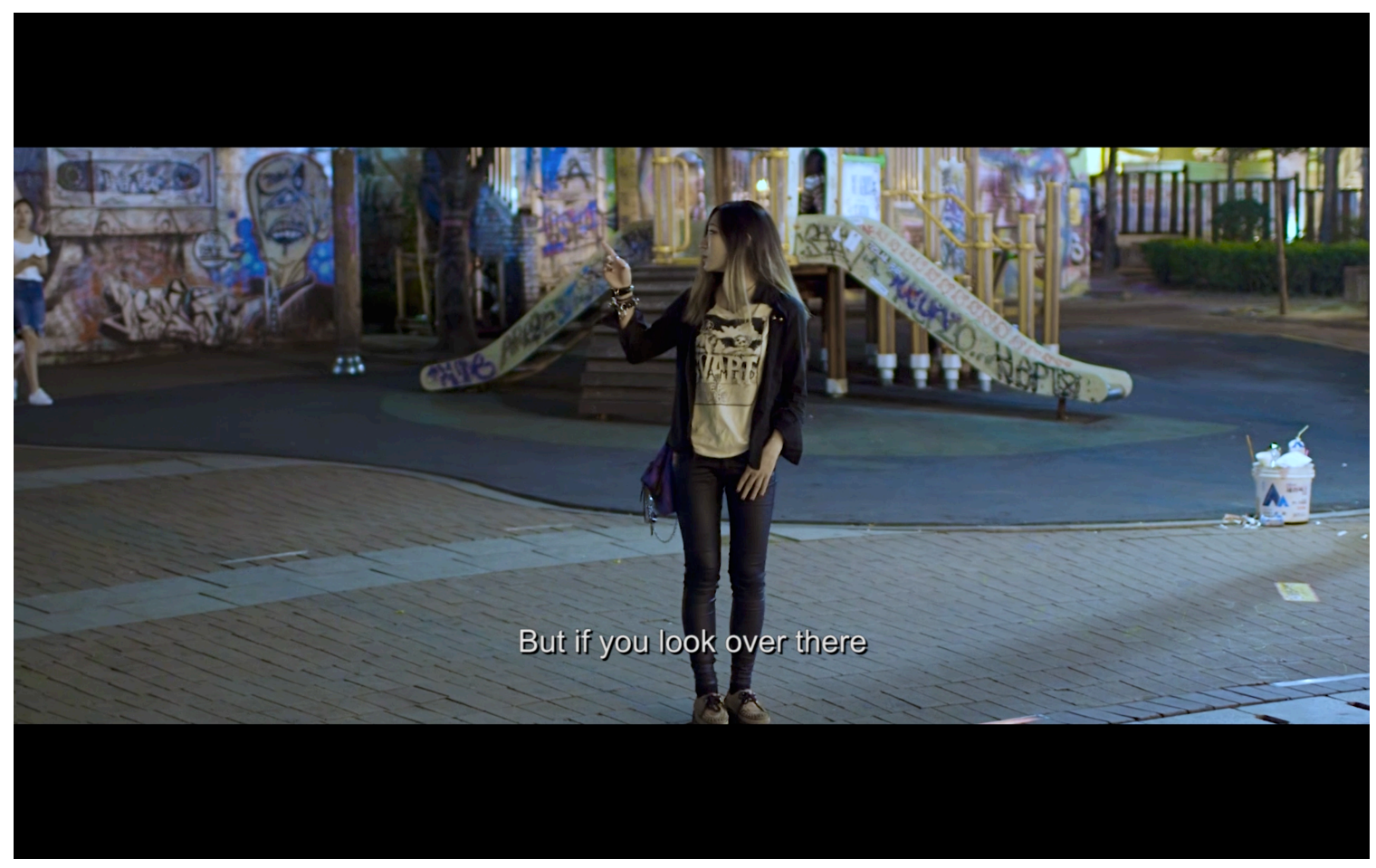

Juyoung in front of the Hongdae park washrooms.

Christine Hine argued that "ongoing social changes lead to a homogenization of young people's experiences, ${ }^{41}$ The gnashing of Neo-Liberal teeth and the economics of rejuvenation from Park Chun Hee's time have certainly seen to this reality in Hongdae. ${ }^{42}$

What was different about this phase of Hongdae's gentrification was how quietly it happened. The tried and true method is to often intimidate and displace residents then wholesale demolish a neighbourhood. ${ }^{43}$ This can be seen in the film Party $51+(2014)$. It

\footnotetext{
${ }^{40}$ Jon Dunbar, "Playground", Broke in Korea 24, 8 http://www.daehanmindecline.com/broke/broke24.pdf

${ }^{41}$ Christine Hine, Virtual Ethnography. 1st ed. (London: SAGE, 2000), 79-80

${ }^{42}$ Dae-oup Chang, 162

${ }^{43}$ Ji Youn Kim, 135-136, Kwon et al., 3, Porteux, 375-380
} 
portrays a roar of resistance in the face of developers. Ash simply follows the last quiet breath out of Hongdae and stops where it lands.

In the intro to Ash Akhee states that Hongdae is both dead and dying, I can now state that for Korea's punks, Hongdae is dead. The For Lease signs have been replaced by franchises and the streets have been filled with newcomers, consumers, and the apathetic. There are a few venues holding on, but none of them are overly sympathetic to booking punk bands. Ash is now just another collection of detritus strewn to the wind by development.

\subsection{Social Rebellion}

Punk culture is defined by an emphasis on resisting the primary cultural order. ${ }^{44}$ As such Ash focuses on personal impetus and each character's need to exist. For a better understanding of the outward facing elements of punk or similar sub-cultures, a film like Global Metal (2008) explores how music acts as a cross cultural grammar across the world. For anyone wishing to explore SHARP and other punk ideologies, Skinhead Attitude (2003) provides a fascinating social history of Skinhead ska and punk. Ash is missing much of the sub-cultural exposition of the above films but still describes key elements of any punk scene.

Scholar Edwin M. Lemert states that, "societies have a cultural structure separate and distinguishable from a social structure, the former consisting of 'an organized set of normative values', the latter of 'an organized set of social relationships." ${ }^{.45}$ Through this

\footnotetext{
${ }^{44}$ Parkinson, p 155

${ }^{45}$ Edwin M. Lemert, Charles C. Lemert, and Michael F. Winter. Crime and Deviance : Essays and Innovations of Edwin M. Lemert (Lanham: Rowman \& Littlefield, 2000), 59
} 
logic I was able to reduce the themes in Ash to a total of four categories; marriage and children for women, mandatory military service and conservative culture for men. These umbrella constructs represented how the amalgamation of traditional and contemporary values complicate the present-day struggles against the neo-liberal economy in which Ash's characters live. ${ }^{46}$

As was discussed earlier, the efforts of Park Chung Hee and his successors made it so that Nationalism and Confucianism served as cornerstones for modern Korean development. Ideas forged over one thousand years of history have since merged with militant $21^{\text {st }}$ nationalism and created a society obsessively rigid in its push for homogeneity. ${ }^{47}$ As there are few places where one can comfortably hide their deviance, this conservative culture creates a stronger than normal pressure to conform. ${ }^{48}$ Heirarchies themselves are built through a progressive process, thus having Akhee explain how the military plays such a key role in the gradual creation of hierarchical thinking in Korea was key to helping clarify these themes in $A s h{ }^{49}$

Scholar Park Chong Min argues that although those in Korea's past exploited traditional values to push their agendas, this generation has begun to undo them and redefine them. ${ }^{50}$ This persistent resolve to maintain one's identity is represented in one of my favourite sections of the film, Hoonee's daily routine as a pharmacy trainee. Near the

\footnotetext{
${ }^{46}$ Andy Furlong, and Fred Cartmel, Young People and Social Change: New Perspectives. (Maidenhead: McGraw-Hill/Open University Press, 2007), 71, Kim, Eungi, 38-40

${ }^{47}$ Andrew Eungi Kim and Park Gil-sung. "Nationalism, Confucianism, Work Ethic and Industrialization in South Korea." Journal of Contemporary Asia 33, no. 1 (2003): 37-49, 38, 39, Lee, Kwan-Chun et al., 233, 234, 236, Chi, pp, 162, 163

${ }^{48}$ Chong-Min Park and Doh Chull Shin. "Do Asian Values Deter Popular Support for Democracy in South Korea?" Asian Survey 46, no. 3 (2006): 341-361, pp, 344, 347, 349, Lee Kwan-Chun et al., 253-254

${ }^{49}$ Melvyn L. Fein, Human Hierarchies: A General Theory, (New Brunswick USA: Transaction Publishers. 2012), 30

${ }^{50}$ Park, Chong-Min, p, 361
} 
end of his work day we watch Hoonee remove his lab coat to reveal a Siege band t-shirt underneath. The labcoat acts almost like cosplay for a normal life, as underneath is his true self, a determined artist waiting patiently to continue to develop their craft.

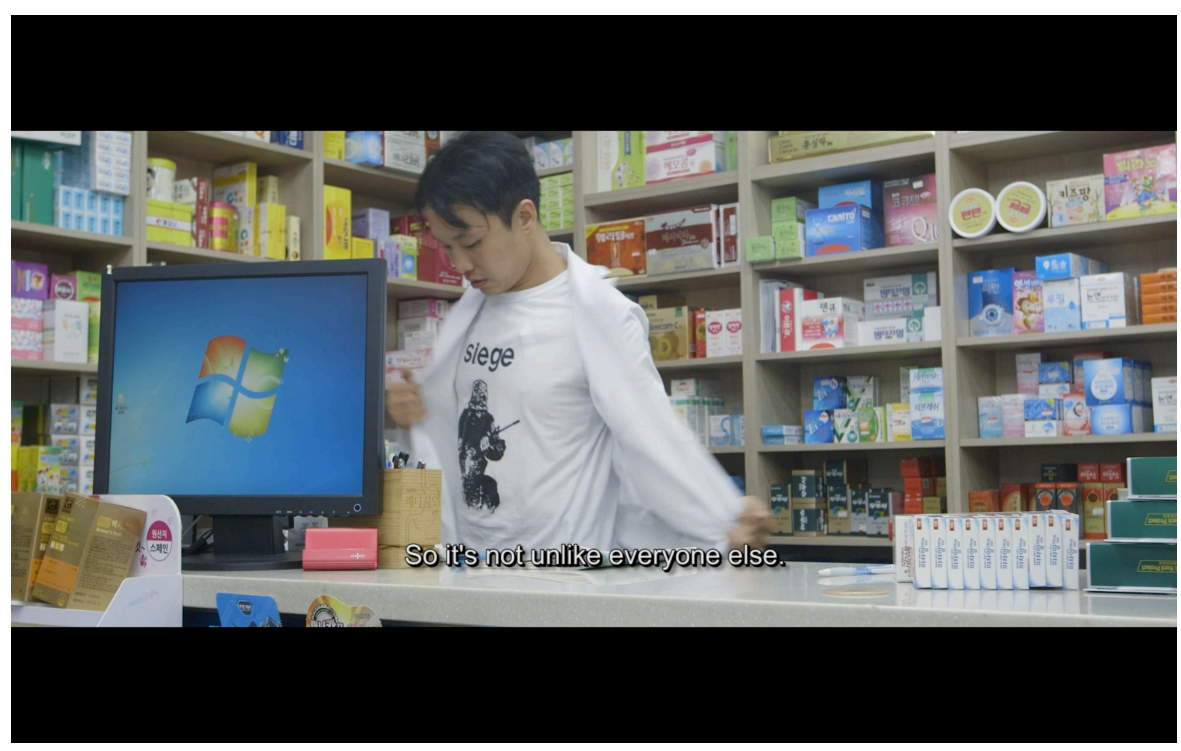

Hoonee revealing his shirt.

Within this struggle to rebel is also the search for gender parity, where traditionalism and patriarchy serve as the biggest blocks to finding equality. ${ }^{51}$ Tight professional spheres crafted by the men in Korean society make it difficult for women to enter politics and other influential careers. Simultaneously tightly constrained social domains, exacerbated by military service, perpetuate the idea that women have a life path fundamentally different from men. ${ }^{52}$ The old-fashioned idea is that women are meant to

\footnotetext{
${ }^{51}$ Eunkang Koh, "Gender Issues and Confucian Scriptures: Is Confucianism Incompatible with Gender Equality in South Korea?" Bulletin of the School of Oriental and African Studies 71, no. 2 (2008): , 346, 347, 353

${ }^{52}$ Kyung Jin Oh, "Women's Political Participation in South Korea and Activist Organizations." Asian Journal of Womens Studies 22, no. 3 (2016):, 339
} 
spend the middle years of their lives as wives and mothers, strongly established gender roles from which deviance is incredibly difficult. ${ }^{53}$

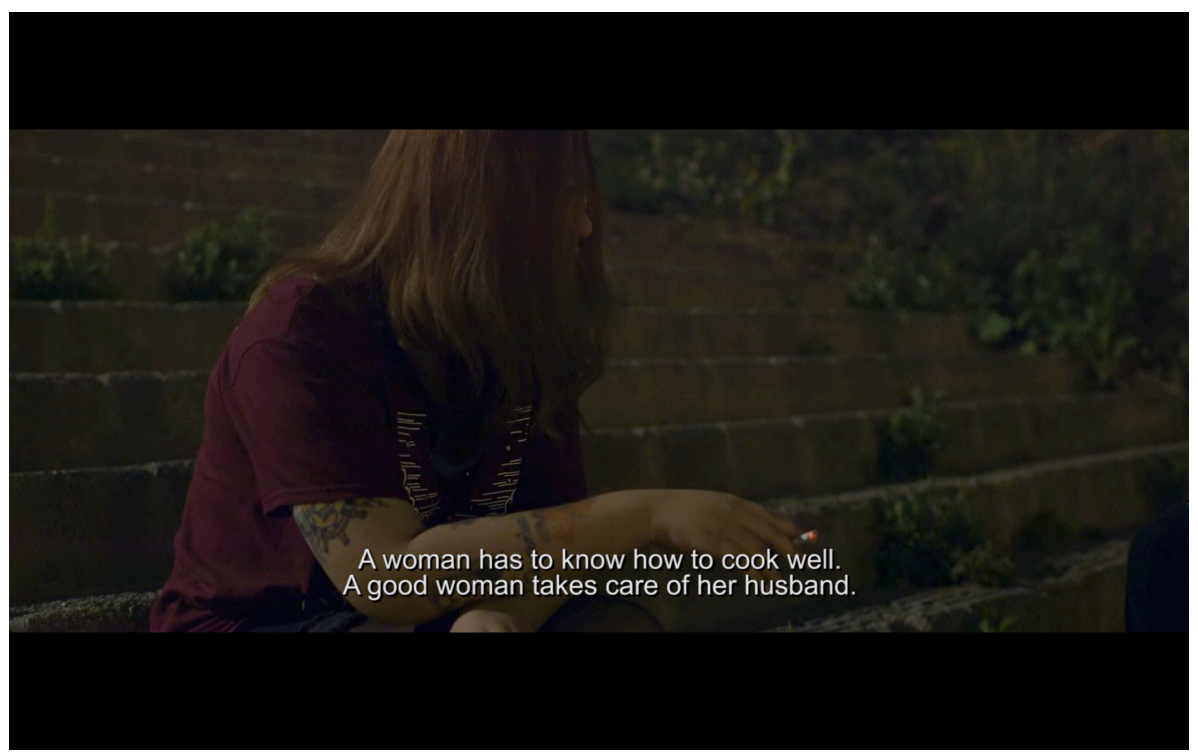

Songi expressing what she believes conservative people think.

In the economy this is reflected firmly in labour patterns where women are statistically recorded as leaving the workforce at childbirth and re-joining only when those children have joined the age of majority. ${ }^{54}$ It is within the punk scene that you do find a large number of female artists. And it is not just singers or visual artists.

Anecdotally I have seen far more instrumentalists, lighting techs, and sound people in the various music scenes in Korea than I have in my comparative experiences in Canada. In theory punk and feminism both encourage women's participation in music and offer them a space (or scene) to perform alternative femininities. ${ }^{55}$

\footnotetext{
${ }^{53}$ Sohee Lee-Mok, "Gender-Sensitive Sex Education for the Youth in Korea." Asian Journal of Women's Studies 20, no. 2 (2014): 173-84, 178

${ }^{54}$ Koh, Eunkang, 357, Jayoung Yoong, "Labor market outcomes for women in East Asia", Asian Journal of Women's Studies Vol. 21 , Iss. 4. (2015), 399

${ }^{55}$ Pauwke Berkers, "Rock Against Gender Roles: Performing Femininities and Doing Feminism Among Women Punk Performers in the Netherlands, 1976-1982," Journal of Popular Music Studies, 24 (2012), 156
} 


\subsection{Art}

The need to practice art to survive is the last central theme in Ash. In Korea, and by conjecture most of the neo-liberal world, bureaucrats generally view cultural properties through their potential create economic benefit. ${ }^{56}$ The characters in Ash are not making a so-called living out of their art but they are certainly alive. Whether they have tertiary streams of income that include tattooing, tutoring, or other non music related careers, they find a way to gain satisfaction in their lives by continuing to develop their artistic practice.

In much of today's world capitalist consumption patterns are the prime determinants of culture, particularly for youth. ${ }^{57}$ Ash's characters can be seen to be working within this type of society but only by terms that work best for them. On existing within capitalism, contemporary punk rock pioneers Refused are quoted as saying, "Most people that work, make money, that's part of life. It doesn't, however, make you a capitalist and I think people should know that...but making money does not make you a capitalist. It's an important distinction." ${ }^{58}$ Capitalist or not, the characters of Ash exist outside of the standard neo-liberal pressures of their society. Art is an extension of self, not of a bank account.

This type of artistic pursuit is in itself deviant as in modernity market forces also shape leisure patterns. ${ }^{59}$ Within this structure opportunities for pluralism grow as the density of commercialised cultures and sub-cultures creates spaces for non-compliant

\footnotetext{
${ }^{56}$ Park Se Hoon, 178

${ }^{57}$ Furlong, 72, 82

${ }^{58}$ Lachlan Marks, "Refused on lying, selling out and Taylor Swift." Faster Louder, June 24, 2015, http://fasterlouder.junkee.com/refused-on-lying-selling-out-and-taylor-swift/843957.

${ }^{59}$ Furlong, 151
} 
individuals to exist in.$^{60}$ However, in Korea's context the ever-present din of Confucian hierarchy presents a strong reminder of how things should be ordered. It is why in unused interviews and conversations Akhee repeatedly mentioned that this generation's punks have defined themselves based on the rejection of age and race based discrimination, age being of particular significance in the Korean context. As a result, participating in a commercially non-viable artform that rejects contemporary consumption patterns represents a firm rejection of the social hierarchies that are endemic to human societal development. ${ }^{61}$

The failure to fit in can cause a large amount of mental duress on individuals. In Ash this is represented by the scene with Lee Pyeong An Scene and his struggles with a culture that "...stresses norms of social obligations and collective good and the practice of living up to social-relational standards." ${ }^{92}$ The interruption of a friendly phone call at the end represents the panacea that subculture provides to the characters in Ash.

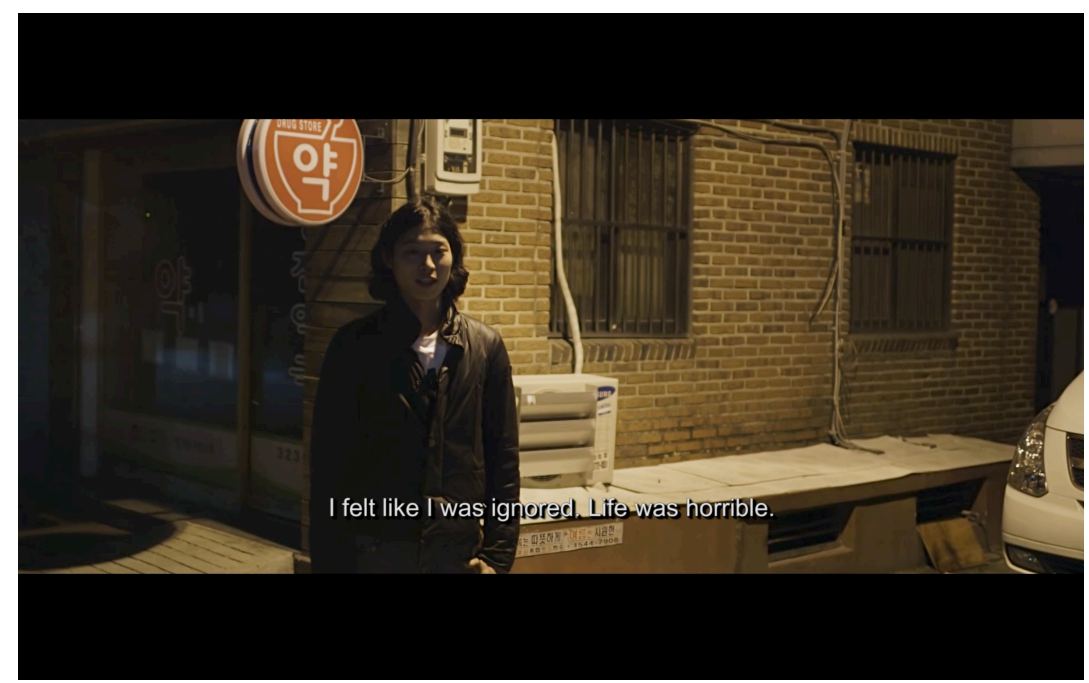

Lee Pyeong An talks about isolation

\footnotetext{
${ }^{60}$ Lemert, 96

${ }^{61}$ Melvyn L. Fein, Human Hierarchies: A General Theory, (New Brunswick USA: Transaction Publishers, 2012), 28, 29, 44, 45

${ }^{62}$ Chong Min Park, 344
} 
Though up until now this paper reads something like a broad sweeping critique of tradition, it should also be noted that the restrictions of conservatism can also be made more comfortable by positive aspects of tradition. ${ }^{63}$ The constant desire for selfimprovement made obvious in Ash can be traced back to Confucian philosophy with celebration of self development and of the generalist. ${ }^{64}$ The art comes from an internal struggle and that struggle is never without compromise or adaptation.

The characters in Ash have pride in their art but not in the nation nor in the economics. I can only assume from reading researched precedent that a drift towards nationalism or the embrace of the Korean neo-liberal reality would result in the erasure of what created the subculture in $A s h .^{65}$ Thus it is precisely the commitment to continuing their art, despite the impossibility of a social or economic victory, that has lead to its existence. To quote Dick Hebdige, “...once in the mainstream subculture loses its deviance and significance." 66

\footnotetext{
${ }^{63}$ Furlong, 71

${ }^{64}$ Kwan-Chun Lee, 251, Kim Andrew, 44, Jesook Song, "“A Room of One's Own': The Meaning of Spatial Autonomy for Unmarried Women in Neoliberal South Korea." Gender, Place and Culture 17 (2010), 142

${ }^{65} \mathrm{Chi}, 162,163,176$

${ }^{66}$ Dick Hebdige, Subculture, the Meaning of Style, (London: Methuen, 1979), 130
} 


\section{Methodology}

I wanted Ash to be something like a fanzine. I made it in an attempt to balance the energy and chaos of a punk show while delivering the intimacy of a private conversation. ${ }^{67}$ The following section details the various stages and struggles of this journey.

\subsection{Pre Production}

My connection to the Korean underground solidified in 2012 when I began to actively photograph concerts. Prior to this, my main interactions were a dozen or more of concerts attended between 2008 and 2011. After I started posting photos online in 2012 they spread quickly through social media and, before I knew it, were showing up on DIY releases. The majority of my work was unpaid as DIY economies are often small and income is rarely a top priority. Through hard work, showing up, speaking some Korean, and being sure to show respect and kindness, I became well connected with the community. If you want to know how to get access, the answer is through hard work, being accessible, and above all else, being transparently non-exploitative.

When I came to Ryerson I wanted to make a feature length film that took audiences through Pacific Asia, we would explore punk ideology through the various communities in Japan, Korea, Indonesia, Singapore, and Malaysia. As evidenced by Ash, I abandoned this original concept. For one, the realities of budgeting and logistics were irresolvable. Second, through discussions with Don Snyder it became clear that the volume of material I was looking to capture would dilute my ultimate aims for the documentary I had in mind.

\footnotetext{
${ }^{67}$ Teal Riggs, "Scissors and Glue." Journal of Design History 19 (2006), 70
} 
After scaling back I developed an idea called Our Voices. It was going to be a didactic approach to documentary and would focus on musicians, their style of music, and how and why they chose to pursue the art form they loved. It was a dry take on a complex issue and a half-baked attempt to celebrate an alternate way of living. Worse still, the way it was received in class was extremely disappointing. I wanted audiences to be inspired by people who inspired me. Instead, the first reaction would be to question the legitimacy or honesty of my potential characters. It was like the subjects of my film were poseurs, colonised victims in the east that had no choice but to parrot the art styles of their western superiors. I wanted my audience to listen to my subjects, even to look up to them. Having them looked down upon was appalling. It was precisely the kind of reading that I wanted to avoid. Somehow Our Voices presented my subjects as the other rather than as normal. Through this unintentional othering I was destined to have audiences perceive these characters exactly the opposite of how I intended. Exactly the opposite of how one should. ${ }^{68}$

I needed to reinvent the project. I had to return to the stacks. The following quotation is where Ash found me, “...punks needed to be rooted in and products of a specific environment in a specific historical moment. ${ }^{, 69}$ It was obvious. In order to tell the story about this scene I needed to situate both the characters and the audience in the appropriate cultural context. Echoing the words of my Islamic studies professor Dr. Meena Sharify Funk, I needed the audience to meet my characters where they were at.

\footnotetext{
${ }^{68}$ Carl R. Plantinga, 2009. Moving Viewers: American Film and the Spectator's Experience, (Los Angeles, University of California Press, 2008) 194

${ }^{69}$ Eric Hertz, "The Anxiety of Authenticity: Post-Punk Film in the 2000's," in Kirsty Fairclough and Benjamin Halligan, The Music Documentary: Acid Rock to Electropop. (New York:

Routledge, 2013), 131
} 
Beyond the 1970's, Punks have been like an immune response to social ills. They represent either society's illnesses or solutions. I organised my research around this principle and I started to explore various socio-cultural themes through this lens. The majority of my pre-research focused on ideas of youth culture, dissidence, deviance, and contemporary Korean history. From this I was able to outline some of the key concepts that shaped my interview direction. General themes such as hierarchical culture, the legacy of Japanese colonisation, and Korea's pre-democractic history provided me with a strong contextual background. I started to draft up a list of people whom I thought would fit well with the project and started to plan my next steps.

In April of 2016 I felt confident that I could film the documentary I had in mind. I purchased my plane ticket and, to most everyone's surprise, my friend Lee Dong Woo released his documentary 노후대책없다 No Money No Future (2016). Immediately I started to worry that his film would make mine redundant. So, I did the most mature thing I could think of. I pretended that the film did not exist and continued with my original plans. Just slightly altered for the sake of safety and sanity.

I assumed that people in Seoul might be a little camera shy now that another documentary was out in the open. Worse still, a lot of the characters in Dong Woo's film were the ones that I wanted to focus on. I had intended to set up a very clear shooting schedule but scrapped that idea in response. My new plan was to show up, walk the streets of Hongdae like I used to, and run into the people that I knew or that knew me. This way I would be able to get participation organically. I bet you can guess how well that plan worked out. Gentrification, right? Regardless, I was still able to find participants. Nobody who is in the documentary felt forced and most felt excited to contribute. My 
soft approach also allowed unexpected additions to the cast such as Songi and Angie, whom I approached at practices rather than through formal communication.

A final note on style, in pre-production I decided to shoot all of my interviews with the characters centre frame. By doing so, I would be able to structure each interview in the direct address style, with the character speaking to the camera. ${ }^{70}$ To accommodate this I had to choose between two aspect ratios, $4: 3$ or $2.35: 1$. I ended up choosing $2.35: 1$ and subsequently shot all of my footage with this aspect ratio in mind. My hope was to have the audience engage with characters rather than identify with them. This way I could aim to establish a critical distance and encourage greater empathy. ${ }^{71}$

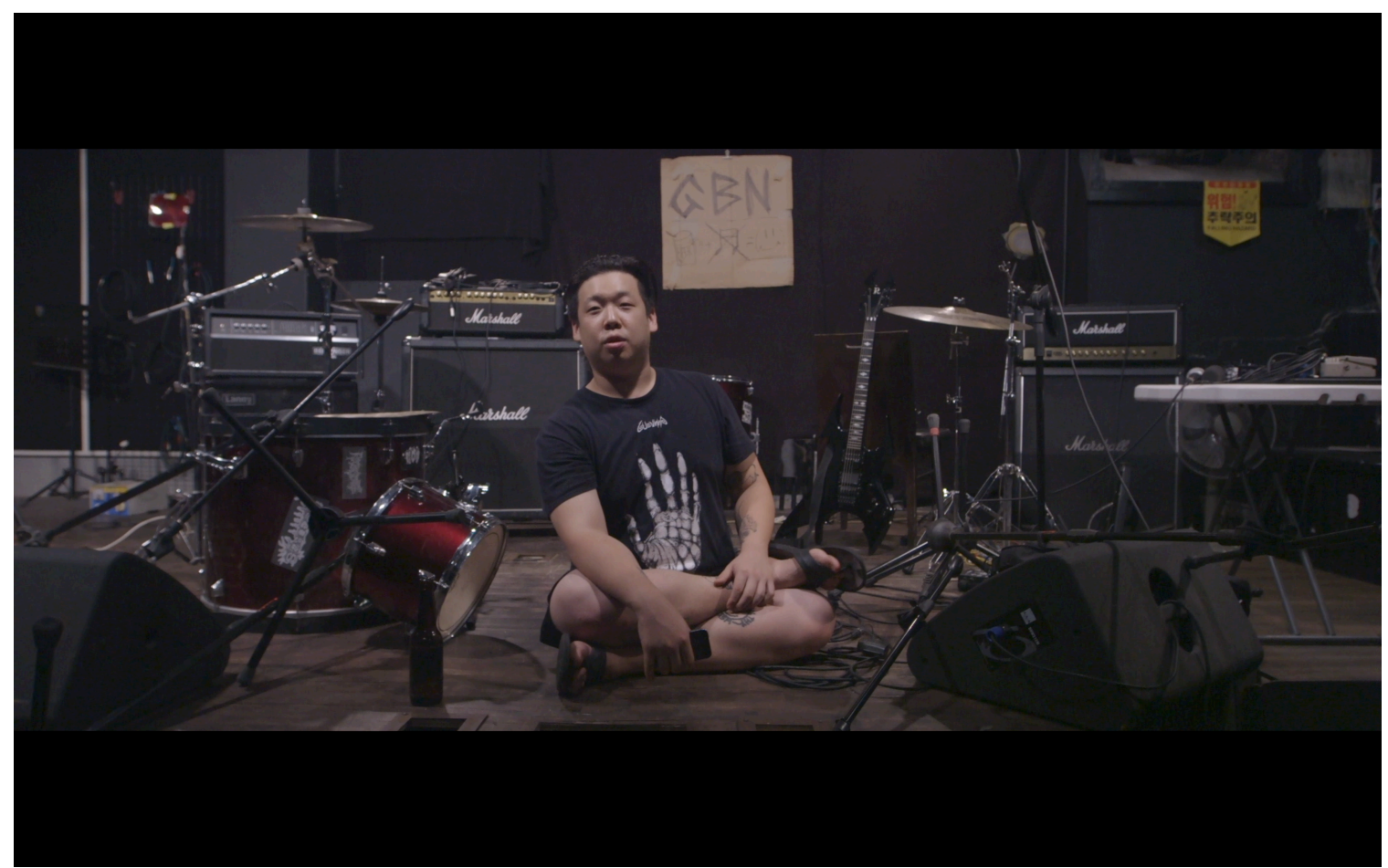

An example of the 2:35:1 framing

\footnotetext{
${ }^{70}$ Rhodes, 255

${ }^{71}$ Carl Plantinga.'The Scene of Empathy and the Human Face on Film', in Carl Plantinga and Greg M.Smith (eds), Passionate Views: Film, Cognition, and Emotion (Baltimore, MD: Johns Hopkins University Press, 1999), 242-244
} 


\subsection{Homebase}

Once in Seoul I made sure to get housing as close to Hongdae as possible. As mentioned, rapid gentrification had started to change the area into a cultural desert and it was now a place where random run-ins were few and far between. In the first week, it became clear that serendipity would not guide me through the next two months. However, even though Hongdae was nearly clear of artists, it gave me the fastest routes to reach crucial parts of the city.

During this first week I was invited by the character Jiwon to visit Club Sharp and watch a practice. Once the usual greetings were finished I set up my tripod and started to record the practice. Hongdae was dead. I felt it at that moment. Club Sharp, with its fresh paint but nostalgic tone was like a fort set up to defend against invasion. I started to ask myself where the scene had gone. I also started to wonder where it was going.

During this practice, another key character, Bum Joo, became acutely interested in the project. His help would inevitably lead to some of the better moments of the documentary, including the interview with Pyeong An. Without Bumjoo, some of the more difficult to schedule interviews would not have happened.

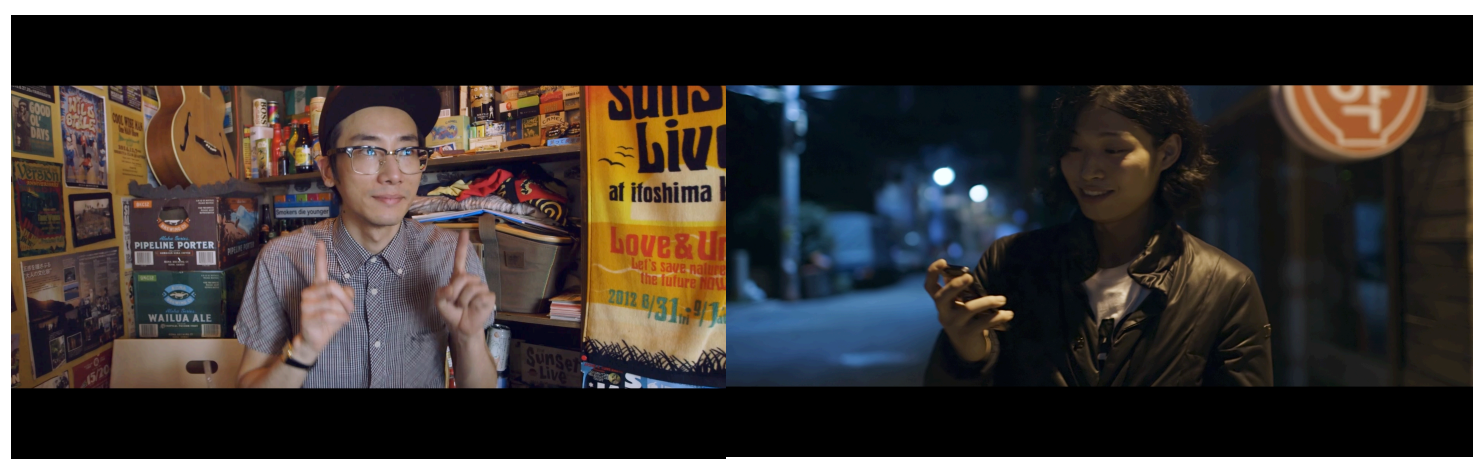

Bum Joo (left) and Pyeong An (right) 


\subsection{Interviews}

Ash's focus is the various socio-cultural ills that my characters feel in life. So as not to lead my subjects and create my own narrative, I came up with the idea in preproduction of having characters describe what their Korea was in a single word. I had intended for this to help me pinpoint some key social themes while also giving me airtight section headers to work with when editing. The concept fell apart during an unused interview with Victor Ha. Halfway through an answer Victor started to look upset. He moved his gaze from the camera lens to my face and told me that he hated the question. It was too flat, too general. He looked angry. Before Victor, a few characters had also had trouble answering this question. Looking back, it was probably because they were feeling the same way. After Victor's interview I never asked this question again.

From this point on I allowed interviews to flow organically. As I talked more and more with male characters two key themes kept coming up, military service and conservative people. From these two concepts came a vicious circle of societal pain. From conservative people came the maintenance of military service and from military service came the conservative people. It was from this cycle that much of the societal pressure that the characters in my film face in their every day lives. ${ }^{72}$

When I was interviewing female characters for the film two separate social pressures were consistently and conveniently repeated; marriage and children. To quote scholar Yoong Jayoung, "Female employment is largely affected by life cycle stages wherein women's bio-logical functions and social roles intersect." ${ }^{, 73}$ There were several moments during interviews where subjects would throw their hands down in frustration

\footnotetext{
${ }^{72}$ Lee Mok, 178, Lee Kwan-Chun, 234

${ }^{73}$ Yoong, 398
} 
when thinking about what their future could be. The key problems faced by women intersected with those of men. All of it could be traced to a persistent and pervasive patriarchy borne from traditionalist call-backs to the 60's and 70's which have been continually reinforced through to modern times. ${ }^{74}$

Eventually, with a clear interview direction the biggest issue I faced was the actual scheduling of interviews. Seoul is a 24-hour city with a work day that reflects this reality. Outside of disparate nights and days during the weekends, my participants were busy with work, overtime, or social obligations that could not be cancelled. Getting people in front of the camera often meant asking them to sacrifice what little extra time they had for sleep or leisure. If anybody was wondering why so much of this film happens at night, well, there is your answer.

\footnotetext{
${ }^{74}$ Koh, 346, 347, 353, 357, Oh, 339, Song Jesook, pp, 134-135
} 


\subsection{Locations}

One of the key visual considerations for Ash was the interview backgrounds. For each scene it was important to pick a location that was both visually appealing and in possession of symbolic meaning. Doing so allowed me to give additional layers to the subjective reading of $A s h$. The actual selection process ended up being simple as each character often had a place in mind whenever asked. One of the more subtle backgrounds was selected by the film's second narrator, Ahn Akhee.

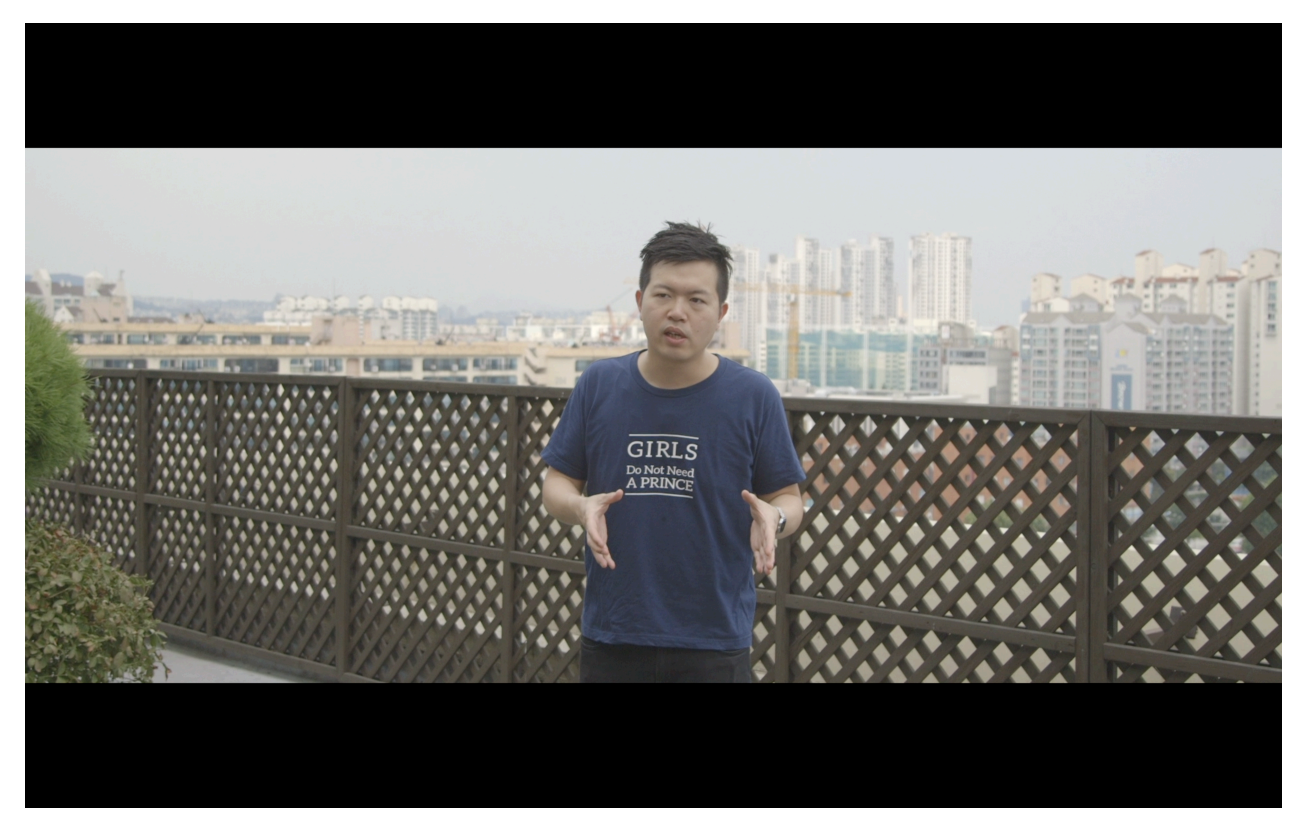

Akhee atop the Seoul Bus Station Terminal

The location chosen was the rooftop of the Seoul Bus Terminal. Behind Akhee lay the endless apartment towers of central Gangnam. Not only did these towers represent the past and present of Seoul's gentrification, but it was also the location where Korea's first punks came from. The bus terminal also holds a subversive semiotic value. In the 90's and early 2000's the Seoul Bus Terminal rooftop was a popular cruising spot. Akhee's claim over this location plants him firmly within the DIY history, culture, and narrative and helps to further the social-deviance narrative in the film. 
Yet, if the viewer is never told what the background locations are, how can it be anything but just a pretty picture? This was the fun part for me. With the exception of the three venues, Hongdae Playground, GBN Livehouse, and Club Sharp, no other interview location is explicitly explained. Korean viewers, or those familiar with Korea, have a chance to recognise certain elements in each background and thus find ways to place them in their appropriate civil and cultural context. With this in mind attentive viewers can make connections and draw their own conclusions from visuals alone. What's more, the backgrounds allow curious viewers to do research based on visual elements in order to learn more about the various characters on screen. Trash, for example, can be seen drawing in some of her candid shots. Her interview, however, takes place in something that looks like a clinic. From these two types of scenes it can be easily deduced that she is involved in some kind of tattoo studio. It is never revealed whether she is artist or apprentice as we only ever see Jinsuck tattooing. This kind of referential visual narration is a common feature of punk zines, and was important in the creation of Ash's visual narrative. ${ }^{75}$
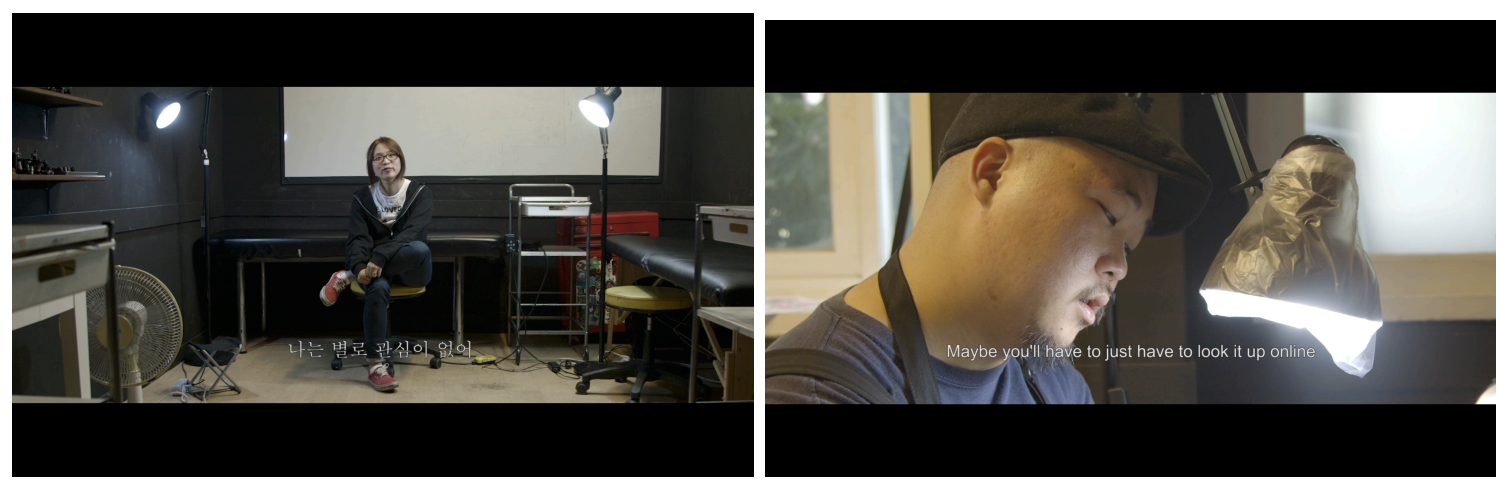

Trash in the studio (left) and Jinsuk tattooing (right)

\footnotetext{
${ }^{75}$ Riggs, 73
} 
The reduction of clarity but increase of density was essential in establishing Ash as a punk film. Complete legibility would betray the iconoclasm of punk identity and $\operatorname{art}^{76}$ while layering in both visual and narrative elements ensured that artefacts of the punk scene could be represented and celebrated without sacrificing the agency of each character and object. ${ }^{77}$

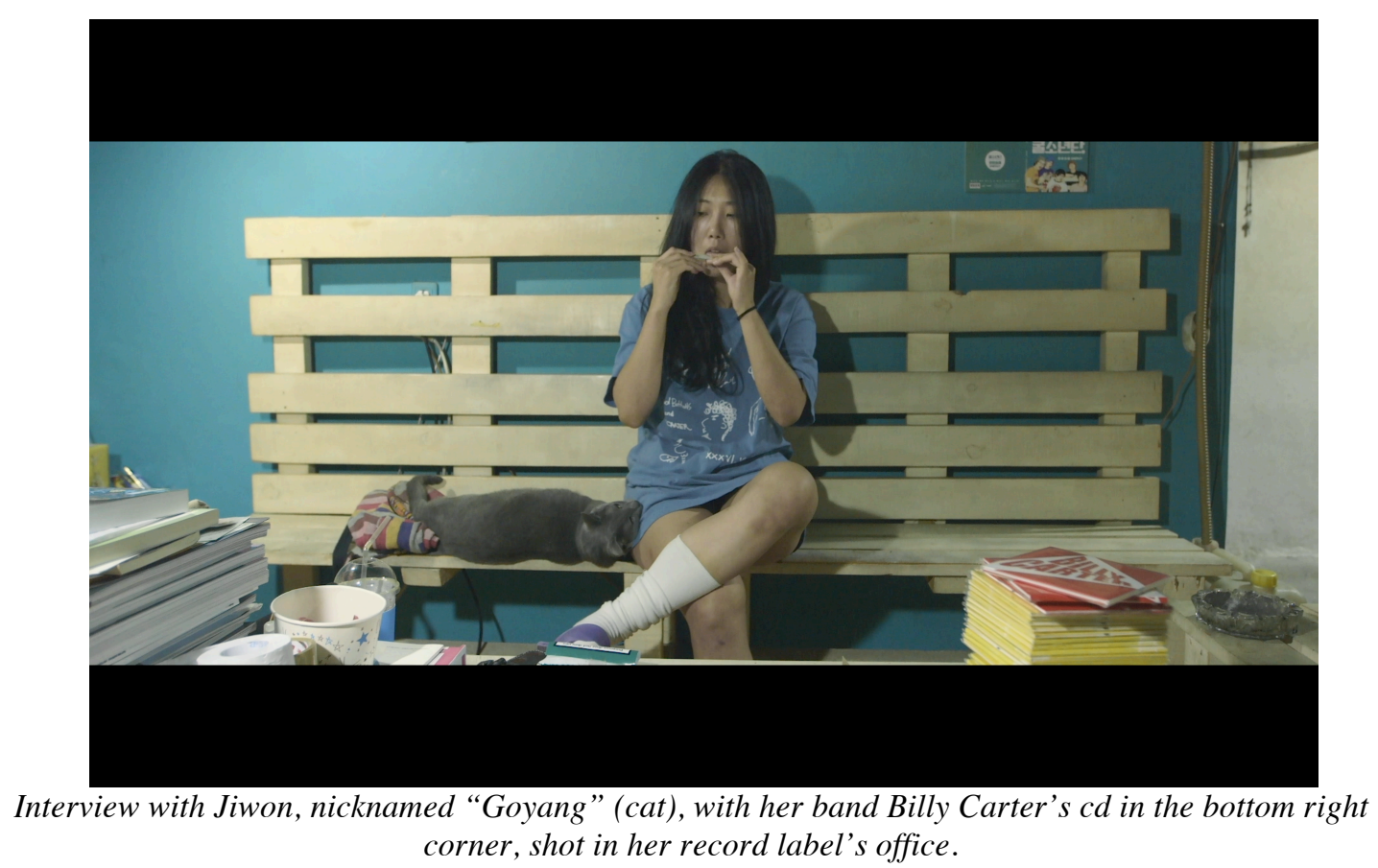

\subsection{Post and Pace}

In September 2016 the story of the documentary I was making followed the development of two music festivals, gentrification and society served as mere undertones. During a December meeting with Gerda Cammaer I lamented that I was having trouble balancing the various parts of my narrative. She could see it. I was stuck. Even with my transcripts I was unable to put anything together. The story was woefully complicated

\footnotetext{
${ }^{76}$ Barbara A. Misztal, The challenges of vulnerability: in Search of Strategies For a Less Vulnerable Social Life, (Houndmills, Basingstoke: Palgrave Macmillan, 2011), 29

${ }^{77}$ Thompson, 9
} 
and the story elements were too different to be sorted together logically. She told me as directly as possible, I needed to drop one of the storylines in order for this piece to survive. I heeded her advice and Ash was quick to follow.

After our honest conversation, I started to rethink the documentary and move social issues to the forefront. As a result the music in the film started to act almost like punctuation marks, adding period, question mark, or exclamation point to a particular phrase. This allowed me to focus less on music as the main subject and more on the characters' words. Songs worked as an undertone for the film; shortened bars or buzzing feedback acted like a cognitive echo throughout each scene.

\section{Documentary Relevance}

My approach to documentary is one that does not rely heavily on films in the academic canon of documentary cinema. The works that inspire and influence me are those that focus on subcultures and people of limited or trivial significance. In alignment with this, punk often looks to elevate the anybody's of history into a place of significance. So I suppose that my approach is apropos for the subject matter ${ }^{78}$ It has been observed that academics with a similar viewpoint feel that the academy can be oppressive towards punk ideas, I hope that the previous and the following sections suitably justify my positions and approach. ${ }^{79}$

In making Ash I wanted to be as utilitarian as possible with each frame and sound bite when editing. To make this possible I tried to borrow from a vast number of styles and approaches. If we refer to the extremely punk rock and counter cultural magnate Bill

\footnotetext{
${ }^{78}$ Stacy Thompson, "Punk Cinema," Cinema Journal 43, no. 2 (2004): 54

${ }^{79}$ Parkinson, 146
} 
Nichols, Ash fits into the poetic, expository, participatory, observational, reflexive, and performative modes of documentary ${ }^{80} A s h$ also fits into the live performance and musical documentary categories. But within all of this, how can I define Ash as anything other than ash? Simply put, Ash is a punk film. This means that it is intrinsically obligated to fight against standard convention. Far beyond narcissism, this meant that I was able to work around regular practice of subcultural representation and endeavour to use techniques and humour that appealed to the characters and culture in my film.$^{81} \mathrm{I}$ embraced contradiction and set forth to make Ash.

\subsection{Where Ash is unavoidably a Music Documentary}

Although all of Ash's characters are musicians, I did not want Ash to be a music documentary. My aim instead was to create a music documentary that was not about music at all. Songs and performance only serve as the hook for attention and the isthmus between ideas. However, this does come with some narrative complications.

Martin Shelton states that a work's, “...effectiveness is determined by the degree to which the audience becomes involved in experiencing vicarious identification." ${ }^{.82}$ On its surface Ash is about music. This is undeniable. But I wanted audiences to connect with the human stories inside the music scene. I needed to accept that without the appropriate thematic and visual grammar, Ash would never connect with people. A critical point to deliver focus on in a music documentary is making sure that the viewer feels like they are

\footnotetext{
${ }^{80}$ Bill Nichols, Introduction to Documentary, (Bloomington, IN: Indiana University Press, 2001), 99

${ }^{81}$ J. Prinz, "The Aesthetics of Punk Rock", Philosophy Compass, 9 (2014), 589, 590, Riggs, 74, Thompson, 48, 50

${ }^{82}$ S. Martin Shelton, Communicating Ideas With Film, Video, and Multimedia: a Practical Guide to Information Motion-Media, (Carbondale: Southern Illinois University Press, 2004), 70
} 
part of a live audience ${ }^{83}$ If people wanted a show, I needed to give it to them. Failing to provide genre elements that the audience was expecting would be like communicating in English without pronouns. Obtuse formless perplexing communication.

I edited Ash so that an audience's familiarity with music and concerts, a la the Rockumentary, would guide them from the beginning of the piece until the end. ${ }^{84}$ The music was a mere trick to convince audiences to listen to people they may have otherwise felt compelled to ignore. I remember a comment after the first Doc Now screening, an audience member initially felt like they were going to hate Ash because of the punk theme. However, by the end, not only did they find the piece inspiring, they even started to enjoy the music. Mission accomplished?

6.2 Where Ash tries really hard to not be a standard music doc

In the process of consciously avoiding contention, there was an additional pair of Western music documentary conventions that I wanted to subvert. As argued in the introduction to the collection The Music Documentary: Acid Rock to Electropop, the Western tradition of music documentary has always been victim to two shortfalls; that it has largely ignored non-western forms of music and music scenes, and that it often alienates the audience by focusing too much on the performer ${ }^{85}$

Music documentaries often aim to preserve the "proper" public persona of their subjects, meaning the performer rather than the person is exalted. Unlike Anvil: The Story of Anvil, where characters are seen in their full vulnerability and personal reality, we are

\footnotetext{
${ }^{83}$ Thompson Punk Productions, 161, 162

${ }^{84}$ Liz Giuffre, "I'm not dead yet : music documentary's role in asserting and celebrating artistic independence and resilience," Studies in Australasian cinema, Vol. 8, No. 1, (2014), 44-55, 45

${ }^{85}$ Edgar et al., 14
} 
often given a piece more reminiscent of Skinhead Attitude (2002) or The Filth and the Fury (2000). The typical music documentary works on a level of adulation and surreality that celebrates subculture as a commodity and force of nature. What I wanted to do was to present a subculture as an identity and a source of life, an alternative answer to modernity.

Although I do have a personal and ethical interest in preserving the integrity and dignity of my characters, I did not want to in portray them in an idealised or caricaturised form that could result in caricaturised interpretations ${ }^{86}$ Thus, their protective public persona was something that needed less emphasis. I needed to give viewers the version of Ash's characters that these characters rarely, if ever, let the audience see. Throughout Ash I use the public/performative persona in juxtaposition with their private selves ${ }^{87}$ This keeps the audience in line with the expectation that they are going to see performers performing. Ash then sneaks various social messages to an audience who was not expecting such an approach. By maintaining this connection between artist and audience, a hallmark of the genre, the artists in Ash are able to inhabit a more conversational space. $^{88}$

Like a good conversation, I wanted Ash to stick with people. I did not want it to be consumed in the traditional sense. I wanted it to be digested. Like the ringing in your ears when you get surprised without earplugs, I wanted the loudness within Ash to mean something after recovery.

\footnotetext{
${ }^{86}$ Edgar et al., 19

${ }^{87}$ Leigh H. Edwards, "Reality Television and Documentary Forms" in Docufictions: Essays on the Intersection of Documentary and Fiction, (Jefferson : Mcfarland and Company, 2006) 256, 257

${ }^{88}$ Giuffre, 45
} 
6.3 Where Ash is actually just a show

One of the more subtle narrative devices I used in Ash was to edit the film as if it were a concert. In our current era of social media, the gig, the concert, or just simply being part of a crowd is imperative. ${ }^{89}$ Within music documentary the camera can often be seen as playing the part of the audience. ${ }^{90}$ I wanted to emphasize this with Ash and take the audience from set up to take down.

The beginning of the film represents preparation for the show. We see shots of people practicing and setting up a stage. Several shots introduce the idea of a sound check and a gathering audience. Then, as the narrative continues we are moved into the tattoo studio above the concert hall where we can hear the subtle drum tones of the preparation beneath. Once Jinsuk is finished his speech scenes we are taken to the basement where the tones of suicide city start to play and the first song begins. ${ }^{91}$

Throughout the film songs act as punctuation marks between scenes. However, an alternate perspective is that the interview and observational section of the film serves as rest spaces between songs. Much like the progress through a set list, time is often taken between songs to talk to the audience, tune instruments, and rest.

Most transparent is the last act of the film that begins affectionately with the Kitsches singer Jae Hyeon announcing, “This is the last song!" Before the last song begins we are given images that make it seem like the night has progressed and the audience has thinned. The touring headliner (the audience) has reached its peak and now

\footnotetext{
${ }^{89}$ Thompson Punk Productions 12

${ }^{90}$ Thompson Punk Cinema, 161, 162

${ }^{91}$ Appendix A, The lyrics of Suicide City represent some key concepts in the film. Another Easter egg.
} 
it's almost time to go home. The familiar hometown band (the scene/recap) is now on stage as we glide through the denouement.

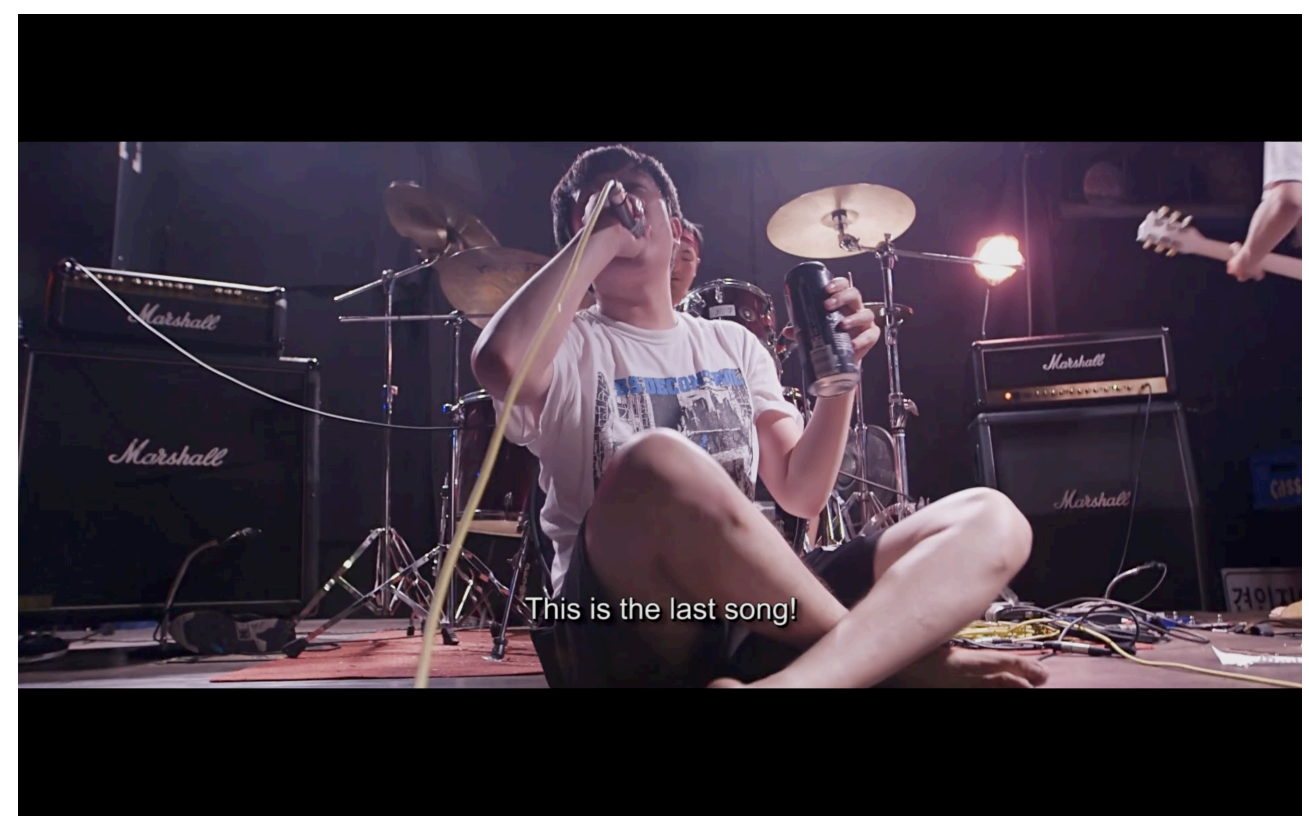

Jae Hyeon announcing the end of the show.

With no fanfare, the film fades to credits, silence the sound of the city muted behind damaged ears. Exit stage wherever.

\subsection{Punk Documentary}

In his exploration of British punk subcultures Dick Hebdige observed that punk often seeks to separate itself from conventional methods of art and structure. ${ }^{92}$ Punk, a style based on ideas of autodidactism and amateurism, requires this kind of internal and personal control in order to be of the genre..$^{93}$ As a punk production, this allowed Ash to become whatever I wanted it to be. Far beyond narcissism, this meant that I was able to scorn typical approaches to subculture representation and, as a result, create a product

\footnotetext{
${ }^{92}$ Hebdige, 19

${ }^{93}$ Tom Parkinson, 2017, "Being Punk in Higher Education: Subcultural Strategies for Academic Practice," Teaching in Higher Education 22 (2017), 154
} 
that paradoxically fits the ideal of punk cinema, that being the conscious evasion of convention..$^{94}$

But first, we need the experts again. If we refer back (already) to our friend Bill Nichols, ASH follows six sub genres; poetic, expository, participatory, observational, reflexive, and performative. ${ }^{95}$ That's a lot of space to occupy, isn't it? But remember, non-fiction and documentary are open concepts.$^{96}$ For Ash I operated under what Carl Plantinga calls an open structure; a film that relies on an open ended and ultimately weak exposition to tell its story. ${ }^{97}$ Much of the scenes' history and origins remains hidden in order to let ambiguity and vagueness drive curiosity. This allowed me to work within a looser rule-set and allowed the narrative to be built organically. The basic concepts of gentrification, scene building, and a quest for coffee, are almost red herrings that are only there to keep the audience interested. The rest of the film acts as a delivery vehicle for the introduction of disparate bands and characters.

But what is punk style? It is simply put an adherence to an anti-aesthetic. ${ }^{98}$ Though it may possess its own unique markers of style and identification it often seeks to define itself by what it is not. For Ash this meant employing deliberate rule breaks in composition and editing. Doing so would help me to exploit the "shock effect" by using the betrayal of a viewer's understanding of content to create scenes. ${ }^{99}$

\footnotetext{
94 Thompson, 168

${ }^{95}$ Nichols, Bill, 99

${ }^{96}$ Plantinga Rhetoric 15

${ }^{97}$ Plantinga Rhetoric, 141

${ }^{98}$ Prinz, 588

99 David Laing, "Listening to Punk," in The Subcultures Reader. (London: Routledge, 1997), 455,456
} 
One of these approaches was to have characters talk to each other outside of a given setting. ${ }^{100}$ Though these scenes should have been jarring, they give humour and atmosphere to the piece instead. These moments also possess a hidden density that, depending on what context the audience brings to Ash, allows viewers to have multiple subjective readings of these moments.

Ash also fits into the language of punk documentary by its choice of themes. Intrinsically, Korean punk aligns well with global punk movements as it stands as a response to the neo-liberal realities. ${ }^{101}$ The day-to-day hardships of an arts community who not defined by economics sounds pretty punk to me.

I had intended to add even more visual character to the piece by using elements of punk design and colouring. I wanted Ash to be stylised, to resemble to the hand hewn typewritten aesthetic of punk zines. ${ }^{102}$ Time and skill limited my ability to execute these goals. The use of the stencil and courier fonts is one of the last remaining remnants of my attempts and, begrudgingly, the piece is probably stronger this way.

Without over manipulating my images, I was able to have the film's editing and humour stand out as the obvious design choices. Keeping some of the more chaotic parts of the edit in the final product did not come without argument, but it goes without saying that, "The off-putting character of punk aesthetics serves as a filter, attracting those who feel marginalized and deterring those who wish to be conventional." ${ }^{103}$

\footnotetext{
${ }^{100}$ The two scenes are Pyeong An's phone call with DongWoo and Shut Up Jeff

${ }^{101}$ K. Dunn, "If It Ain't Cheap, It Ain't Punk": Walter Benjamin's Progressive Cultural Production and DIY Punk Record Labels” Journal of Popular Music Studies, 24 (2012), 218,219

${ }^{102}$ Riggs, 72

${ }^{103}$ Prinz, 590
} 
Of course, the irony of both punk culture and my attempts at differentiation was that Ash still resembles the works that have inspired it. The individuality is in the historicity of the piece, the fact that it takes place in such a fleeting moment.

\subsection{Direct Address}

Early in pre-production I had decided to film my interviews with centre weighted composition. My intention was to have the audience look my characters in the eye and to have my characters look back at the audience. On the small screen the effect was one of an intimate conversation between friends. On the big screen? Well...

S. Martin Shelton states that, "the talking head is the death knell for effective communication, ${ }^{, 104}$ for somebody making an interview documentary (i.e. me) this was something shocking to read. If talking heads do indeed cause an audience's eyes to glaze over, for speakers to be objectified, for ideas to be lost, then how can you deliver both a talking head and a message? I found my answer to this through studies in reality TV. It is something called, direct address. Reality TV shows film their testimonials with characters isolated and in centre frame. By having characters address the camera directly, reality TV directors and producers have stumbled upon a style that not only breaks standard rules of composition but also the way in which audiences approach on screen characters. By moving characters to the centre, they found that they could increase empathy while also maintaining attention spans. ${ }^{105}$

One of the more surreal parts of screening Ash was watching people watch the end of Trash's interview. In test screenings, seeing a monitor or classroom projection

\footnotetext{
${ }^{104}$ Shelton, 152

${ }^{105}$ Edwards, 253, 255, 268
} 
sized Trash was entertaining. Seeing a 20 metre Trash pointing out at the audience telling them exactly who she was and what she was going to do, simply unreal. To date audiences have consistently laughed, cheered, and thrown compliments at the screen whenever this section appears.

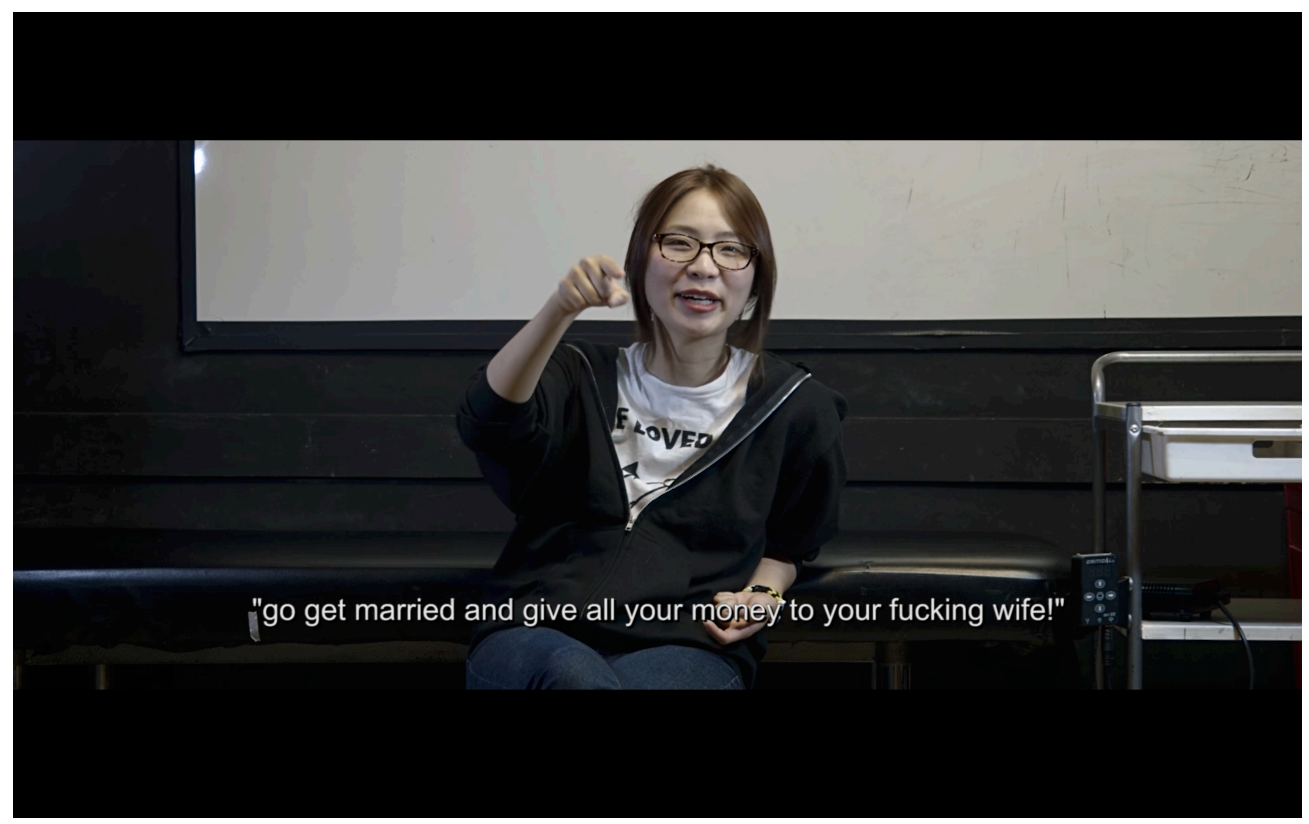

No caption necessary...

But why was it important for me to have this kind of direct audience connection?

Personally, my opinion is that overly identifying with characters can problematize the reading of a narrative. Too often viewers begin to replace the realities of on screen characters with their own. The paradox, however, is that without identification audiences will often stop paying attention. ${ }^{106}$ Direct address was my solution. Using this in combination with current theories of social psychology helped to increase the comprehensibility of the film. Modern audiences tend to want to belong to something. ${ }^{107}$ The camera now serves as their eyes. ${ }^{108}$ Music and sound can trigger an initial response,

\footnotetext{
${ }^{106}$ Plantinga Empathy, 244

${ }^{107}$ Edgar et al., 12

${ }^{108}$ Thompson Punk Productions, 161, 162
} 
and, hopefully through the all of the layers I was able to inspire some sort of emotional contagion, “... an automatic and involuntary affective process that can occur when we observe others experiencing emotions." 109

6.5 Subculture Representation - Ash as punk cinema // Ash as subcultural documentary On representation, Carl Plantinga argued that accurate representation does not always guarantee a trusting audience. ${ }^{110}$ Since $A s h$ does not follow the direct cinema mode, I was less concerned with perfectly accurate representation of events and characters. Instead, I focused more on the representation of their social struggles and realities. Cinemania (2002), a film about social outsiders with no inherent "future" was a film I consistently referred to when deciding how to portray the characters in Ash. It took characters with lives and character features that were atypical and quite deviant from convention and made them seem almost normal.

As a piece of punk cinema, it was important for Ash to push against conventions and establish almost a sense of dissonance in the narrative. Dick Hebdige stated that “...punk seeks to detach from normalised forms..."111 Using simple editing tricks, rule breaks in composition and design, and keeping the overall feel of the film handheld and/or intimate, I aimed to keep the audience's gaze parallel with the characters in the film. Nothing feels overly produced or planned and essentially all of the spaces in the film are ones that the musicians inhabit.

\footnotetext{
${ }^{109}$ Amy Coplan, "Catching Characters' Emotions: Emotional Contagion Responses to Narrative Fiction Film." Film Studies Film Studies 8, no.1 (2006), 24

${ }^{110}$ Plantinga Rhetoric, 216

${ }^{111}$ Hebdige, 19
} 
In Ash's subcultural portrayal I wanted to find the best ways to elicit empathy from the audience. Stylistically, this meant that Ash partially relies on what Thompson describes as the DIY aesthetic of punk art and business. Deliberate images and a slightly hand crafted feel. ${ }^{112}$ Mixing style with the flow of ideas, I hoped to avoid a critical thought disabling sympathetic narrative and instead tried to make one that inspired empathy, the congruent and vicarious feeling of another's emotions. ${ }^{113}$

\subsection{The Stuff that B-Roll is made out of}

A lot of documentaries that are filmed in foreign countries rely on the same tropes of visual representation, the visuals that one expects as a tourist; an Eiffel tower, the Statue of Liberty, the Forbidden City, the Sidney Opera House. Often they are objects that locals may not encounter or even acknowledge on a given day. For certain, key landmarks and symbols can work as powerful establishing shots for an audience but they often do little to replace the tourist's gaze with one of a local's. When capturing my b-roll I wanted to shoot images that informed an unaware audience, served as establishing shots like those mentioned above, and also acted as readable images for a local or informed audience.

Seoul in July and August is hot. Really hot. Seoul in July and August without the monsoon is hotter. Much Hotter. The air quality in China in July and August is much cleaner when the G20 is coming to town. With cleaner air from China, Seoul's sun is much hotter in July and August. Can you guess the theme here? When filming Ash I lost a lot of daylight hours recovering from the heat. Dragging heavy gear across the city was

\footnotetext{
112 Thompson, 159

113 Plantinga Empathy, 191, 245
} 
taxing. I had to plan carefully and work accordingly. This often meant foregoing days of crawling the city to find b-roll if to instead focus on interviews. Trying to speak another language, monitor audio, care for focus and composition, and run a competent interview was consistently difficult when dehydrated and near heat stroke.

I went back to Seoul in 2017 with the intention of getting some pick up shots to replace b-roll that I was less than happy with. The temperature was cooler, the monsoon added some reprieve to the daily heat, but gentrification had literally erased parts of the city that I wanted to reshoot. In some ways I am relieved that this keeps Ash in the objective realm of historicity. Though not always the most beautiful of shots, the b-roll in Ash is accurate, of the time, and geographically relevant.

\section{Drifting Smoke}

At the time of this film's production I entered into what had quickly become a cluttered sub genre of punk rock documentary. When I was about to begin production, my friend Lee Dong Woo released his film No Money No Future (2016), a direct cinema style film that follows the tour of the bands Scumraid and Find the Spot. Recently veteran director Jung Yong Taek released his film Bamseom Pirates Seoul Inferno (2017), which looked at the political and legal struggles faced by the band Bamseom Pirates in the aftermath of the arrest of photographer Park Jung-Geun after he jokingly reposted North Korean propaganda to his twitter page. Add to this the two pieces to which I contributed, Us and Them (2014) and the Seoul section of Vice's Under The Influence New York Hardcore (2015), and a plethora of internet micro docs released in the last six months, it was difficult to keep faith in the relevance of Ash. However, with Ash, I believe that I've 
managed to capture the ephemerality of Seoul 2016. Ash holds a remnant of the subcultural spirit in the moments both before and during significant social changes.

I had the opportunity to do a small private screening on July 17 , 2017. I sat in the basement of club Sharp with a group of film participants and scene insiders and held my breath. I was worried about the whole process and it took a lot of prodding from my partner to even set it up. In the end, it was a very valuable experience for me. As an insider/outsider I constantly worried about overstepping the boundaries of my understanding of Korean culture and the scene. Despite living and working in the country for close to seven years, there are still an enormous amount of small details that I was unable to cover through research and life. To my relief the response to the film was positive. The Male audience loved it and laughed and cheered throughout the film. Scumraid's singer Jihwan's response was "I wish I was in there. Blah blah blah society sucks, yeah!" The female audience told me they felt inspired. Jae, a member of the scene for over a decade, remarked that it was nice to see that the previous generation's problems were now being talked about. Particularly that men were now willing to talk about weakness. In her opinion, the macho façade from days past was fading.

At present the future of Korean punk is uncertain. In the year since Ash was filmed bands have broken up and key people have moved from the country. However, Club Sharp and GBN Livehouse have co-operated more and more in that time. Bands that rarely played together are now joining each others' bills and there have even been some Club Sharp X GBN Livehouse shows. I can only hope that Ash can serve as the memory of a unique period in time and as a set of instructions for those who refuse to hear, "no". 
Appendix A

\section{Suicide City Lyrics}

\section{INTRO/CHORUS}

Suicide, Suicide City x 3

We live in suicide city GO!

\section{VERSE 1}

What is happening

In this city of happiness

What is happening

In this city of happiness

You learned how to keep fighting

To be rich endless competition

Competition scars on kid's wrist

Getting more and more and more

CHORUS - Suicide, Suicide City x 3

\section{VERSE 2}

What is happening

In this city of happiness

What is happening

In this city of happiness

You must live to kill people

Around you

You get no more partners

No more friends

If you dont kill

You'll be killed

hang yourself or dive into the river

CHORUS - Suicide, Suicide City x 3

Big city told me you idiot

You gotta die to finish

All that situation

How can we get a good life

CHORUS - Suicide, Suicide City x 3 


\section{Bibliography}

Abelmann, Nancy, So Jin Park, and Hyunhee Kim. 2009. "College Rank and neo-liberal Subjectivity in South Korea: The Burden of self-development." Inter-Asia Cultural Studies 10 (2): 229-247.

Berkers, P. (2012), Rock Against Gender Roles: Performing Femininities and Doing Feminism Among Women Punk Performers in the Netherlands, 1976-1982. Journal of Popular Music Studies, 24 (2012): 155-175.

Buzo, Adrian. The Making of Modern Korea. 3RD ed. New York: Routledge, 2017.

Carothers, Chris. "The Turning Point for South Korean Democracy." The Diplomat. June 27, 2017. http://thediplomat.com/2017/06/the-turning-point-for-south-koreandemocracy/.

Chang, Dae-oup. Capitalist Development in Korea: Labour, Capital and the Myth of the Developmental State. London: Routledge, 2009.

Chi, Eun Ju, Hyeok Yong Kwon, and Yang Ho Rhee. "Perceived Inequality and the Formation of National Pride in Korea." Korea Observer 45, no. 2 (2014): 153.

Choi, Hee Jung and Nora Hui-Jung Kim. 2017. "Of Soldiers and Citizens: Shallow Marketisation, Military Service and Citizenship in Neo-Liberal South Korea." Journal of Contemporary Asia 47 (4): 515-534.

Clinard, Marshall B. Anomie and Deviant Behaviour: A Discussion and Critique. New York: Free Press, 1964.

Coplan, Amy. "Catching Characters' Emotions: Emotional Contagion Responses to Narrative Fiction Film." Film Studies Film Studies 8, no. 1 (2006): 26-38.

Cumings, Bruce. Korea's Place in the Sun: A Modern History. Updat ed. W. W. Norton, 2005.

Dotter, Daniel L. Creating Deviance: An Interactionist Approach. Walnut Creek, CA: Altamira Press, 2004.

Dunn, K. “If It Ain't Cheap, It Ain't Punk": Walter Benjamin's Progressive Cultural Production and DIY Punk Record Labels. Journal of Popular Music Studies, 24: (2012). 217-237.

Dudden, Alexis. Japan's Colonization of Korea: Discourse and Power University of Hawai'i Press, 2005. 
Dunbar, Jon, "Playground". Broke in Korea 24. 2017. http://www.daehanmindecline.com/broke/broke24.pdf.

Edgar-Hunt, Robert, Kirsty Fairclough-Isaacs, and Benjamin Halligan. The Music Documentary: Acid Rock to Electropop. New York: Routledge, 2013.

Fauteux, Brian. 2012. "“New Noise" Versus the Old Sound: Manifestos and the Shape of Punk to Come." Popular Music and Society 35 (4): 465-482.

Fein, Melvyn L. Human Hierarchies: A General Theory. New Brunswick USA: Transaction Publishers. 2012.

Furlong, Andy, and Fred Cartmel. Young People and Social Change: New Perspectives. Maidenhead: McGraw-Hill/Open University Press, 2007.

Gelder, Ken, and Sarah Thornton. The Subcultures Reader. London: Routledge, 1997.

Giuffre, Liz. 2014. "I'm not dead yet : music documentary's role in asserting and celebrating artistic independence and resilience." In Studies in Australasian cinema, Vol. 8, No. 1, (2014), p.44-55.

Hebdige, Dick. Subculture, the Meaning of Style. London: Methuen, 1979.

Hine, Christine. Virtual Ethnography. 1st ed. GB: SAGE, 2000.

Hwang, Kyung Moon. A History of Korea: An Episodic Narrative. 2nd ed. Palgrave, Macmillan Education, 2017.

Kim, Andrew Eungi and Gil-sung Park. "Nationalism, Confucianism, Work Ethic and Industrialization in South Korea." Journal of Contemporary Asia 33, no. 1 (2003): $37-49$.

Kim, Ji Youn. "Cultural Entrepreneurs and Urban Regeneration in Itaewon, Seoul." Cities 56, (2016): 132-140.

Koh, Eunkang. "Gender Issues and Confucian Scriptures: Is Confucianism Incompatible with Gender Equality in South Korea?" Bulletin of the School of Oriental and African Studies 71, no. 2 (2008): 345-362.

Kwon, O. Yul. The Korean Economy in Transition: An Institutional Perspective. Cheltenham, Glos, UK: Edward Elgar, 2010.

Kwon, Yoonku, Shinha Joo, Soyoung Han, and Chan Park. "Mapping the Distribution Pattern of Gentrification Near Urban Parks in the Case of Gyeongui Line Forest Park, Seoul, Korea." Sustainability 9, no. 2 (2017): 231. 
Kwon, Jong Bum. "Severed in Neoliberal South Korea: Cho ‘ngdŭnilt'o and the dis/assembly of Industrial Bodies." Critique of Anthropology 35, no. 4 (2015): 407-429.

Lee-Mok, Sohee. "Gender-Sensitive Sex Education for the Youth in Korea." Asian Journal of Womens Studies 20, no. 2 (2014): 173-84.

Lee, Kwan-chun and Sang Kil Han. "Value Harmony as a Social Capital and EHW Factors in Korea." Korea Observer 38, no. 2 (2007): 225.

Lee, Seung-Ook, Sook-Jin Kim, and Joel Wainwright. "Mad Cow Militancy: Neoliberal Hegemony and Social Resistance in South Korea." Political Geography 29, no. 7 (2010): 359-369.

Lemert, Edwin M., Charles C. Lemert, and Michael F. Winter. Crime and Deviance : Essays and Innovations of Edwin M. Lemert Rowman \& Littlefield, 2000.

Marks, Lachlan. "Refused on lying, selling out and Taylor Swift." FasterLouder. June 24, 2015. http://fasterlouder.junkee.com/refused-on-lying-selling-out-and-taylorswift/843957.

Misztal, Barbara A. The challenges of vulnerability: in Search of Strategies For a Less Vulnerable Social Life. Houndmills, Basingstoke: Palgrave Macmillan, 2011.

Nichols, Bill. Introduction to Documentary. Bloomington, IN: Indiana University Press, 2001.

No, Gyong-Mok, and Sang-Yong Park. "나라 탓하는 '헬조선'... 부모 탓하는 '흙수저'" Hankyung.com. http://www.hankyung.com/news/app/newsview.php?aid=2015100480831.

Oh, Kyung Jin. "Women's Political Participation in South Korea and Activist Organizations." Asian Journal of Womens Studies 22, no. 3 (2016): 338-45.

Pak, Chung Hee. Our Nation's Path. West Gate Seoul: Dong-a Publ., 1962.

Park, Chong-Min and Doh Chull Shin. "Do Asian Values Deter Popular Support for Democracy in South Korea?" Asian Survey 46, no. 3 (2006): 341-361.

Park, Juyoung and Jai S. Mah. 2011. "Neo-Liberal Reform and Bipolarisation of Income in Korea." Journal of Contemporary Asia 41 (2): 249-265.

Park, Se Hoon. "Can we Implant an Artist Community? A Reflection on GovernmentLed Cultural Districts in Korea." Cities 56, (2016): 172-179. 
Parkinson, Tom. 2017. "Being Punk in Higher Education: Subcultural Strategies for Academic Practice." Teaching in Higher Education 22 (2): 143-157.

Phippen, J. Weston. "Moon Jae In Wins South Korea's Presidential Election." The Atlantic. May 09, 2017. Accessed August 21, 2017. https://www.theatlantic.com/news/archive/2017/05/south-korea-presidentialelection/525942/.

Pirie, Iain. The Korean Developmental State: From Dirigisme to Neo-Liberalism. New York: Routledge, 2008.

Plantinga, Carl R. Rhetoric and Representation in Nonfiction Film. Cambridge, U.K.: Cambridge University Press, 1997.

Plantinga, Carl.'The Scene of Empathy and the Human Face on Film', in Carl Plantinga and Greg M.Smith (eds), Passionate Views: Film, Cognition, and Emotion (Baltimore, MD, Johns Hopkins University Press, 1999), pp. 239-255.

Plantinga, Carl R. 2009. Moving Viewers: American Film and the Spectator's Experience. University of California Press.

Porteux, Jonson N., and Sunil Kim. "Public ordering of private coercion: urban redevelopment and democratization in South Korea." Journal of East Asian Studies 16, no. 3 (2016): 371+.

Potter, Kai. "Is Hongdae going south? Only to Hapjeong, Sangsu and Mangwon." The Korea Herald. August 09, 2017. http://www.koreaherald.com/view.php?ud=20170809000801.

Prinz, J. (2014), The Aesthetics of Punk Rock. Philosophy Compass, 9: 583-593.

Riggs, Teal. 2006. "Scissors and Glue." Journal of Design History 19 (1): 69-83.

Rhodes, Gary Don, and John Parris Springer. Docufictions: Essays on the Intersection of Documentary and Fictional Filmmaking. Jefferson, NC: McFarland \& Co., 2006.

Seth, Michael J. A History of Korea: From Antiquity to the Present Rowman \& Littlefield, 2011.

Shelton, S. Martin. Communicating Ideas With Film, Video, and Multimedia: a Practical Guide to Information Motion-Media. Carbondale: Southern Illinois University Press, 2004. 
Song, Jesook. 2010. "'A Room of One's Own': The Meaning of Spatial Autonomy for Unmarried Women in Neoliberal South Korea." Gender, Place and Culture 17 (2): 131-149.

Kim, Suk Kyoon. "The Sewol Ferry Disaster in Korea and Maritime Safety Management." Ocean Development \& International Law 46, no. 4 (2015): 345358.

Thompson, Stacy. Punk Productions: Unfinished Business. Albany: State University of New York Press, 2004.

Thompson, Stacy. "Punk Cinema." Cinema Journal 43, no. 2 (2004): 47-66. http://www.jstor.org/stable/1225914.

Yap, Fiona. How Do South Koreans Respond to Government Corruption. Korean Observer Vol. 47. Iss. 2. 2016. 363-386.

Yoong, Jayoung. Labor market outcomes for women in East Asia. Asian Journal of Women's Studies Vol. 21 , Iss. 4. 2015. Pp. 384-408.

여객선 세 월호 전복사고 특별조사 보고서 ((Sewol Safety Investigation Report), 해양안전심판원 특별조사부(Marine Safety Tribunal). 2014. 


\section{Selected Filmography}

Dunn, Sam. Metal: A Headbanger's Journey. DVD. Canada. 2005.

Dunn, Sam. Global Metal. DVD. Canada. 2008.

Eckman, Meghan. The Parking Lot Movie. United States of America. 2010.

Epstein, Stephen J., Tangherlini Tim R. Us \& Them: Korean Indie in a Kpop World. DVD. New Zealand. 2014

Epstein, Stephen J. Our Nation: A Korean Punk Rock Community. DVD. New Zealand. 2002

Gervasi, Sacha. Anvil the Story of Anvil. DVD. Canada. 2009.

Kijak, Stephen, Christlieb Angela. Cinemania. DVD. Netherlands. 2002.

Lee, Dong Woo, No Money No Future. Korea. DVD. 2016.

Metze Steve. Über Goober. United States of America. 2004.

Ruchti, Lincoln. Chasing Ghosts. United States of America. 2007.

Schweizer, Daniel. Skinhead Attitude. DVD. Switzerland. 2003.

Smith, Chris, American Movie. DVD. United States of America. 1999.

Taek, Jong-Yong. Party 51+. DVD. 2013.

Temple, Julien. The Filth and the Fury. DVD. United Kingdom. 2000.

Winter, Sam. "Under The Influence: New York Hardcore." YouTube. 2015. https://www.youtube.com/watch?v=tRoEdcBgH2Q. 